DOSSIÊ

\title{
Utopia antropofágica e dialética da não contemporaneidade em oswald de Andrade
}

Anthropophagic utopia and dialectics of non-contemporaneity in oswald de Andrade

\section{Felipe Ribeiro*}

DOI: https://doi.org/10.4322/principios.2675-6609.2022.163.007

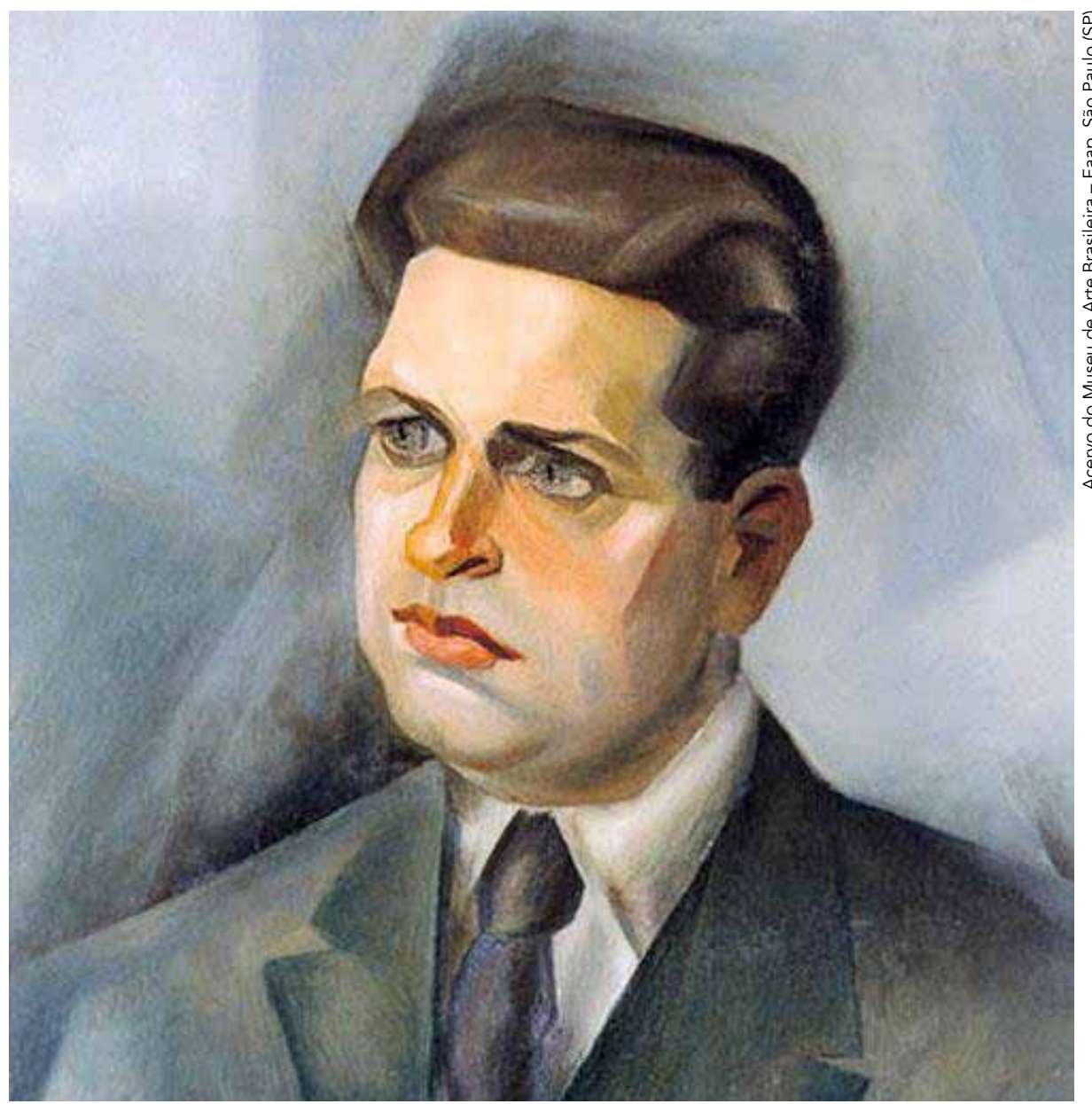

Tarsila do Amaral. Retrato de Oswald de Andrade. 1923. Pintura, óleo sobre tela, 50 × 60 cm. 


\section{RESUMO}

Este ensaio busca descrever os aspectos gerais do que se poderia chamar de "utopia de Oswald de Andrade". Seu núcleo está na alegorização da justaposição entre modernidade e pré-modernidade, que na obra do modernista figura como esperança de uma via própria do Brasil para uma civilização original e superior, que se beneficiaria de um passado de ganhos da civilização moderna, de modo a saltar a etapa do desenvolvimento burguês. Em seguida, o ensaio traça um estudo comparativo com reflexões marxistas muito semelhantes às convicções de Oswald. Trata-se tanto das intervenções de Marx na questão da propriedade comunal russa, entre I870 e I880, como das reflexões de Ernst Bloch sobre a "dialética da não contemporaneidade", em Heritage of our times (herança de nosso tempo). O objetivo da comparação é mostrar a proximidade de Oswald com reflexões que outros autores socialistas desenvolviam a respeito de vias heterogêneas e não etapistas em direção ao futuro pós-burguês, o que poria em perspectiva crítica a necessidade do desenvolvimento das formas capitalistas de produção como condição necessária para uma nova forma social.

Palavras-chave: Oswald de Andrade. Utopia antropofágica. Karl Marx. Ernst Bloch. Dialética da não contemporaneidade.

\section{ABSTRACT}

This essay aims to describe the general aspects of what one may call "Oswald de Andrade's utopia". Such utopia is built by means of an allegorization of the juxtaposition between modernity and pre-modernity, which in Andrade's view figures as Brazil's particular path towards an original and superior form of civilization. This way of civilization could benefit from a legacy from the past and from the achievements of modern society, and skip the steps of bourgeois development. Moving on, the essay makes a comparative study with similar Marxist reflections, namely: Marx's interventions around I870-I880 on the question of Russian communal property and Ernst Bloch's reflections on the "dialectics of the non-contemporaneity". The aim of such comparison is to show the close relation between Oswald de Andrade's utopia and other socialist authors that developed ideas about heterogenous paths towards a post-bourgeois future, setting up a critical perspective around the development of capitalist forms of production as a necessary condition of the new social form.

Keywords: Oswald de Andrade. Anthropophagic utopia. Karl Marx. Ernst Bloch. Dialectics of non-contemporaneity. 
As linhas gerais do que se pode chamar de "utopia de Oswald" podem ser encontradas nos célebres "Manifesto da poesia pau-brasil" e "Manifesto antropofágico", com os quais aquele Modernismo de primeira hora se lançava, com sua "desbragada fantasia”, para usar uma expressão de Antonio Candido (CANDIDO, I973, p. II8), ao público leitor. O prefácio de Serafim Ponte Grande também tem muito de manifesto e pode ser alinhado aos outros dois textos. Fora dos escritos programáticos, a utopia oswaldiana informa muito da própria construção das obras literárias, sobretudo de sua poesia, dos romances Memórias sentimentais de João Miramar e Serafim Ponte Gran$d e$, inclusive alcançando sua produção não ficcional, notoriamente polemista e cheia de energia, hoje recolhida em Ponta de lança e Telefonema ${ }^{\perp}$.

O procedimento geral de Oswald, depois de constatar o fato, consistia num certo enaltecimento da maneira como o Brasil combinava momentos modernos e arcaicos, visando sintonizar nossas particularidades nacionais com a cultura de vanguarda vinda da Europa - o pendor revolucionário - , cujas qualidades podiam ser aproveitadas pela imagem violenta da devoração antropofágica, e como que "desauratizadas", no que ficavam aliás disponíveis para a elaboração das montagens ${ }^{2}$. A verve canibalística, no caso, não era destruidora, como argumenta Candido, mas funcionava para Oswald como "uma estratégia para construir, não apenas a sua visão, mas um outro mundo, o das utopias que sonhou com base no matriarcado" (CANDIDO, I970, p. 77). A presença simultânea do moderno e do pré-moderno, que era, sobretudo, um fato histórico-social do país, deveria ser recolhida por uma poesia atinente ao lado objetivo da vida — para o que servia o preparo vanguardista do espírito - , dando contemporaneidade a elementos dissonantes, num equilíbrio de graça bem brasileira.

No resumo de Roberto Schwarz, a "matéria-prima" de Oswald "se obtém mediante duas operações: a justaposição de elementos próprios ao Brasil Colônia e ao Brasil burguês, e a elevação do produto - desconjuntado por definição - à dignidade de alegoria do país" (SCHWARZ, I987c, p. I2). Com isso, estava lançado um programa que buscava dar forma às singularidades práticas da história nacional, tratando de dar-lhe uma valoração positiva e contemporânea, que, aliás, operaria no lance seguinte como nossa verdadeira contribuição para o mundo, algo como uma via particular para uma sociedade de tipo novo e cuja realização poderia ser alcançada com relativamente pouco esforço.

Enquadrado dessa maneira, nosso legado tradicional, que num primeiro lance obstaria o progresso, não oferece desvantagem ou vexame nesse ponto, pois opera como uma espécie de filtro. Assim, nossos resíduos tradicionais continham um padrão de sociabilidade mais caloroso, anterior à frieza burguesa, que não interessava então dissipar, mas ganhar para uma sociedade futura. É o que Oswald dizia ao argumentar que o Brasil representaria "a vitória da civilização do Sul", mais vantajosa em relação à civilização do Norte, isto é, aos EUA:

\footnotetext{
1 Neste último, como notou Dantas (2015), também já se reconhecem as decepções de Oswald em relação a algumas expectativas desenhadas nas décadas de 1920 e 1930.

2 A relação entre o processo de perda da aura e a montagem dadaísta foi estudada na obra-prima de Benjamin (1983) A obra de arte na época de sua reprodutibilidade técnica.
} 


\title{
Se, onde as relações capitalistas estão
} plenamente desenvolvidas, reina a frieza calculista - o "sádico frigorífico do capitalismo" -, então a cordialidade que a colonização nos legou teria algo como uma solidariedade que se tratava de aproveitar contra as atrofias típicas do capitalismo. Daí a bravata de que já "tínhamos o comunismo"

\begin{abstract}
Se o Brasil é também o Sul, isto é, a mesma expressão de cultura agrária e sentimental, torrão de boa vontade e pátria do melting-pot, aqui não sofremos ainda a interferência deformadora dos grandes parvenus da era da máquina. Ao contrário, entre nós alastrou-se e criou raízes em coordenadas de superior inteligência humana a característica civilização luso-tropical que nos ensinou a igualdade prática das raças e boa vontade como elo do trabalho, da cooperação e da vida. No continente americano, o Brasil é o Sul sensível e cordial que venceu (ANDRADE, 1972a, p. 5I).
\end{abstract}

Se, onde as relações capitalistas estão plenamente desenvolvidas, reina a frieza calculista - o "sádico frigorífico do capitalismo" (ANDRADE, 1972a, p. 5) —, então a cordialidade que a colonização nos legou teria algo como uma solidariedade que se tratava de aproveitar contra as atrofias típicas do capitalismo. Daí a bravata de que já "tínhamos o comunismo" (ANDRADE, 1978b, p. I6).

Num texto dedicado à noção de cordialidade, Andrade (1978d, p. I42) saudará, sobretudo, seus aspectos anti-individualistas, que, sendo matriarcais em sua origem, opõem-se também às culturas patriarcais, burguesas, capitalistas³. A esperança era que os elementos do passado, desrecalcados pelo programa vanguardista, funcionariam como que uma senha secreta para uma via própria em direção ao mundo pós-burguês, com o que pularíamos etapas e evitaríamos as regressões características do aburguesamento social. Isso levou, inclusive, o Oswald de A marcha das utopias (ANDRANDE, 1978a) a ver com bons olhos nosso passado jesuíta, cuja tradição ainda tinha algum vínculo com o cultivo medieval do ócio, diferentemente das religiões protestantes, que estavam em linha com a ética do trabalho racionalizado. Esse tipo de raciocínio, o qual, aliás, era muito recorrente entre os modernistas, dava o seguinte

3 No campo das apropriações marxistas das investigações da psicanálise, foi sobretudo Fromm (1934) quem buscou opor às formas culturais patriarcais e capitalistas as formas sociais de origem matriarcal. 
Nosso Brasil feudal-burguês justapunha

- mais como fato da realidade do que

preferência intelectual - o progresso e

o arcaísmo, com o que Oswald, como se

sabe, antecipou temas fundamentais do

tropicalismo. Tratava-se, então, de ganhar

para a invenção e o plano intencional aquilo

que o desenvolvimento desigual e combinado do capitalismo produzia no plano involuntário

tom geral descrito por Candido (1973, p. I20): "As nossas deficiências, supostas ou reais, são reinterpretadas como superioridades." O argumento converte o atraso relativo e as veleidades atrasadas em vantagens, que dariam um caminho bem brasileiro e diferente do europeu em direção a uma sociedade de tipo superior — o que Schwarz chamará de uma interpretação "triunfalista do atraso". Como se, então, onde a modernização estivesse mais em dia com o nível contemporâneo, as possibilidades de escape fossem reduzidas. No geral, portanto, nos termos de Roberto Schwarz, o tema do que Oswald chamava de "Brasil feudal-burguês" (ANDRADE, I976, p. 67)

adquire uma surpreendente feição otimista, até eufórica: o Brasil pré-burguês, quase virgem do puritanismo e cálculo econômico, assimila de forma sábia e poética as vantagens do progresso, prefigurando a humanidade pós-burguesa, desrecalcada e fraterna; além do que oferece uma plataforma positiva de onde objetar à sociedade contemporânea. Um ufanismo crítico, se é possível dizer assim (SCHWARZ, 1987c, p. 13).

Com isso, é a própria noção do que significa modernização que sai modificada:

Portanto, a modernidade no caso não consiste em romper com o passado ou dissolvê-lo, mas em depurar os seus elementos e arranjá-los dentro de uma visão atualizada e, naturalmente, inventiva, como que dizendo, do alto onde se encontra: tudo isso é meu país (SCHWARZ, 1987c, p. 22).

Daí a celebração festiva da maneira como nosso Brasil feudal-burguês justapunha - mais como fato da realidade do que preferência intelectual - o progresso e o arcaísmo, com o que Oswald, como se sabe, antecipou temas fundamentais do tropicalismo. Tratava-se, então, de ganhar para a invenção e o plano intencional aquilo que o desenvolvimento desigual e combinado do capitalismo produzia no plano involuntário. O tom é sempre de carnaval, como se nota nessas primeiras linhas no "Manifesto da poesia pau-brasil": "A formação étnica rica. Riqueza vegetal. O miné- 
rio. A cozinha. O vatapá, o ouro e a dança." (ANDRADE, I978c, p. 5) Da culinária baiana aos nossos produtos minerais: tudo citado sem hierarquia, fora de seu contexto prático imediato, o que lhes confere uma generalidade feliz. Tudo deve ter seu lugar, nada deve ficar de fora: "Tudo revertendo em riqueza." (ANDRADE, 1978c, p. 5) Nos termos de Paulo Arantes, que resume a "resposta afirmativa" dada "aos dilemas da dualidade" que nossa realidade impunha sem deixar escolhas ao intelectual: "O que o complexo colonial interiorizara como atraso e desgraça, o desrecalque pau-brasil converterá em motivo de euforia, já que a vanguarda emparelhava nosso primitivismo com a cultura dos países centrais." (ARANTES, 202I, p. 46) A modernidade, que vinha de fora, com isso podia ser assimilada como convinha, sem "vira-latismo", e o passado nacional era enquadrado fora do registro da nostalgia, como elemento de atualidade, a ser aproveitado sem saudosismo. O passado em questão não era o passado dos conservadores (até porque as influências psicanalíticas dos modernistas queriam recuperar as reminiscências reprimidas, populares e folclóricas), mas a modernidade tampouco era do progressismo etapista. A provocação acabava sendo dupla, por sua vez: contra a ideologia colonialista, que nada teria que ver com o que era afinidade com a urbanidade e a modernização, mas também contra o universo desta, que era obrigada a conviver, celebrativamente, com pressupostos de uma sociabilidade outra. É certo que não está ausente um elemento senhorial nessa atitude dos modernistas, como quem sobrevoa pelo alto e passeia à vontade entre registros histórico-sociais opostos - mas a pompa é, também, relativizada pelo que há de humor, sarcasmo e satisfação meio brincalhona com o panorama, aliás contra si própria4.

Por outro ângulo, Oswald evitava duas parcialidades que dominaram muito da vida intelectual no Brasil, sobretudo na literatura: de um lado, uma espécie de nacionalismo pitoresco, voltado contra qualquer influência europeia, em busca do Brasil mais puro e sem distorções estrangeiras, o que, no entanto, muitas vezes dava no contrário, numa artificialidade forçada e pouco natural, além de ocultar mal influências estrangeiras ainda assim presentes; de outro, o uso irrefletido e acrítico de formas importadas, sem confronto com o dado local, redundando em imitação pura e simples. Segundo uma reconstrução de Antonio Candido, o verbo literário entre nós oscilou muito entre essas duas posições, com resultados que não são de grande força, sendo somente nos momentos de equilíbrio que sairiam os melhores trabalhos de nossa literatura. Candido cita como exemplo Castro Alves e Machado de Assis, chegando até Mário de Andrade (CANDIDO, 1973, p. IIO). Ora, o que estamos vendo de Oswald poderia ser igualmente incluído nesse podium. O resultado, apesar da leveza brincalhona com que enfrenta os termos da equação, não é por isso conformista, pois, no fim, não deixa intocados os domínios que põe em cotejo.

De maneira geral, a utopia não é nem bem a de um meio termo, pois ambos os componentes estão justapostos, e não fundidos, mas tampouco é a da dialética, que pressupõe antagonismo, crise e eventuais superações. O procedimento de Oswald

4 "Uma das ideias que me seduziram é essa de que a base do humour é feita mais que de autocrítica, de autoflagelação... Quem se esculhamba, sabe esculhambar os outros e até as coisas. As coisas, o mundo das coisas." (ANDRADE, 1972a, p. 75) 
consistia mais em registrar e enunciar as coisas como provocação e choque, no que elas tinham de diferente e dissonante, mas celebrando-as assim mesmo, como se não fosse necessário muito mais do que isso.

No plano da história das ideias do Brasil, veja-se como, com isso, Oswald dava uma solução própria a problemas que há muito interessaram e ainda interessam a intelectuais do país. Em tempos mais próximos, já notamos que o tropicalismo trabalhou com um material da mesma ordem, também com feição afirmativa e carnavalesca. No século XIX, quando a literatura brasileira assumiu sua feição particular, o debate entre Romantismo e Arcadismo, bem como os problemas próprios do Naturalismo, também se defrontaram com a mesma problemática. O pessimismo de Machado de Assis, por sua vez, encarará a coisa em sua feição negativa, o que oferece um quebra-gelo ao entusiasmo com a singularidade nacional referida. Oswald explorava, no ciclo seguinte, um caminho diferente: não se tratava de pôr em antítese o que a civilização trazia e o que restava de nosso passado, mas ver aí a nossa chance histórica, que nos faria entrar na história contemporânea como que dando a volta por cima. Meio século depois, Candido (2015) atinará com uma esperança da mesma ordem, agora num romance anterior aos de Oswald, as Memórias de um sargento de milícias ${ }^{5}$, nas quais a malandragem entre ordem e desordem, ao reproduzir a marcha do país como que em miniatura, prefiguraria "um mundo sem culpa", expressão que nos remete ao "país sem pecados" de Oswald (ANDRADE, I972b, p. 46). Fora da literatura, são questões que se imporão também ao ensaio de interpretação do Brasil da década de I930, ele próprio muito devedor do Modernismo, sobretudo nas figuras de Gilberto Freyre (que será depois muito estimado por Oswald), Caio Prado Jr. e Sérgio Buarque de Holanda. O integralismo, a ditadura instaurada em I964 e, hoje, o bolsonarismo, por outro lado, podem ser vistos como encaminhamentos de direita para o problema.

No domínio da estética, cabe observar como Oswald, apesar do localismo de suas concepções (ou mesmo por causa delas), conseguiu alçar a imaginação vanguardista brasileira ao mesmo plano que as vanguardas europeias, a rigor o que havia de mais avançado no panorama internacional da arte. A intenção, com a utopia antropográfica, era democratizar os procedimentos artísticos, que eram retirados das mãos dos experts e postos ao alcance da pessoa comum, para quem, aliás, a justaposição entre arcaico e moderno era um fato. Daí a observação de Candido a respeito dos escritores de 1922, os quais, não sendo propriamente revolucionários, representavam "um esforço para retirar à literatura o caráter de classe, transformando-a em bem comum a todos" (CANDIDO, I973, p. I64).

Nesse sentido, o objetivo era de oposição ao encastelamento tradicional da literatura, a qual descia ao chão de nossa realidade folclórica, que brilhava como se fosse poesia pronta. Daí o elogio: “Como falamos. Como somos.” (ANDRADE, I978c, p. 6) Muito do registro quase positivista de Oswald, se for permitido falar assim, vem daí, como se então bastasse enunciar as coisas sem mistério algum, a fim de dar em algum resultado literário de nível: "A poesia existe nos fatos", diz a abertura do "Manifesto da poesia pau-brasil" (ANDRADE, I978c, p. 5). Tudo se passa como se fosse necessário

5 Obra do escritor carioca Manuel Antônio de Almeida (1830-1861), publicada em 1854. (N. do E.) 


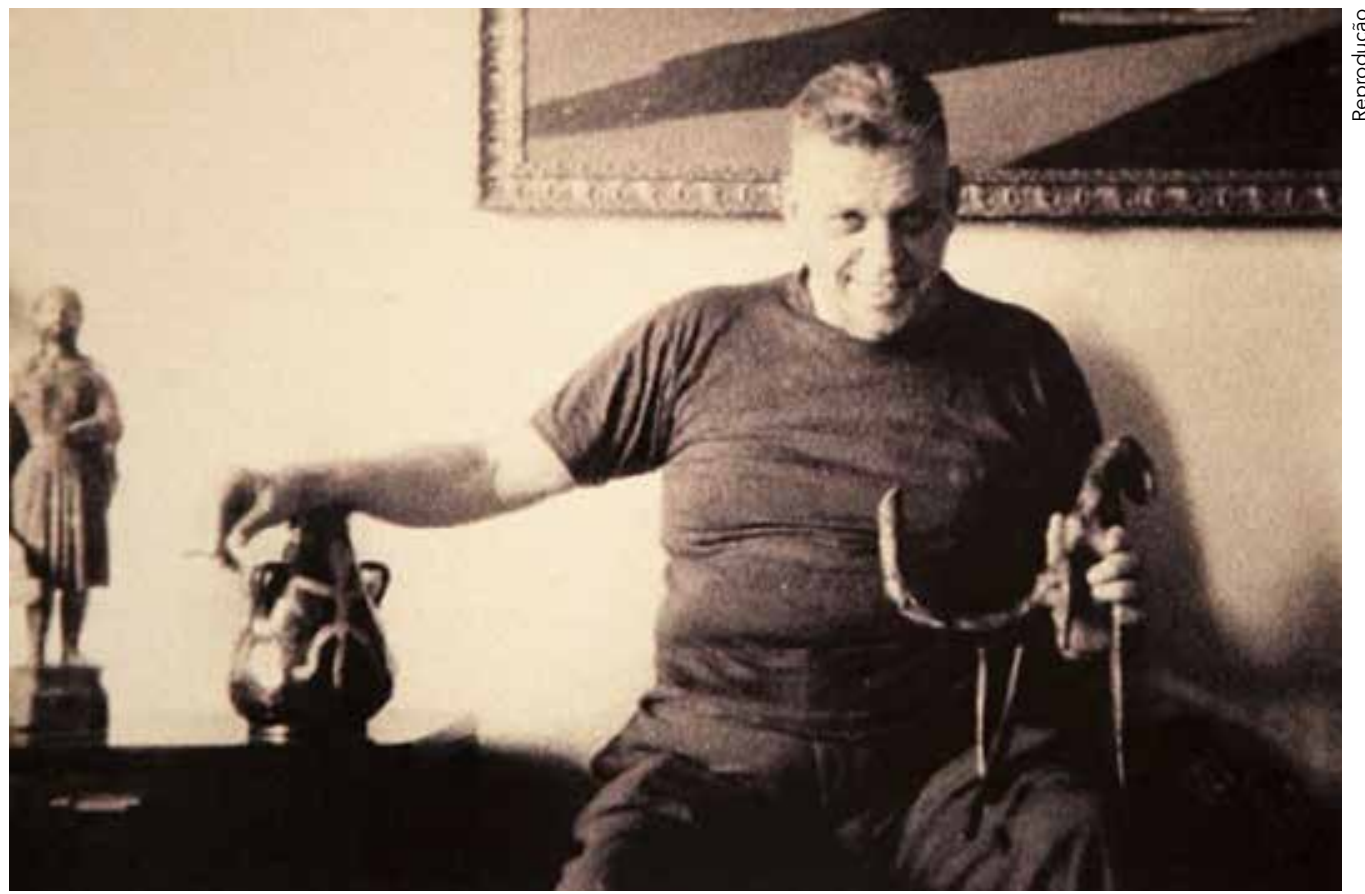

Oswald de Andrade (1890-1954)

ver as coisas de uma perspectiva virgem, depurada de preconceitos: "Ver com olhos livres" (ANDRADE, I978c, p. 9). Fora das ideologias, das camadas de interpretação e, sobretudo, da opressão, a realidade poderia brilhar como ela é: "A realidade sem complexos, sem loucura, sem prostituições e sem penitenciárias do matriarcado de Pindorama”, conclui o "Manifesto antropofágico" (ANDRADE, I978b, p. I9).

Lembro que Lukács (I97Ib), num texto que defende a sátira enquanto método de criação, recordou a frase de Juvenal ${ }^{6}$ segundo a qual "é difícil não escrever sátiras", uma vez que, na cena contemporânea, o próprio curso de declínio do capitalismo e da classe burguesa produzia diariamente materiais satíricos já prontos, exigindo mais o relato imediato do que a intricada mediação literária dos romances realistas. Creio que algo de ordem semelhante foi transferido ao estilo "coisista" de Oswald: o de coletar anedoticamente o que a realidade dava quase de bandeja ao olhar devidamente depurado da herança tradicional conservadora.

No plano funcional global, isso significava elevar nossos dados locais à cena cultural global como contemporâneos dela. O desrecalque localista, operado sobre nossa realidade popular, consistia em mostrar como ela já entregava, meio que pronto, o registro primitivista que estava nos planos das vanguardas internacionais, para as quais, no entanto, isso era uma conquista e um resultado alcançado a duras penas. Segundo uma célebre observação de Antonio Candido:

Ora, no Brasil as culturas primitivas se misturam à vida cotidiana ou são reminiscências ainda vivas de um passado recente. As terríveis ousadias de um Picasso, um Brancusi, um Max Jacob, um Tristan Tzara, eram, no fundo, mais coerentes com a nossa heran- 


\title{
A utopia não é nem bem a de um meio termo, pois ambos os componentes estão justapostos, e não fundidos, mas tampouco é a da dialética, que pressupõe antagonismo, crise e eventuais superações. O procedimento de Oswald consistia mais em registrar e enunciar as coisas como provocação e choque, no que elas tinham de diferente e dissonante, mas celebrando-as assim mesmo, como se não fosse necessário muito mais do que isso
}

\begin{abstract}
ça cultural do que com a deles. O hábito em que estávamos do fetichismo negro, das calungas, dos ex-votos, da poesia folclórica, nos predispunha a aceitar e assimilar processos artísticos que na Europa representavam ruptura profunda com o meio social e as tradições espirituais. Os nossos modernistas se informaram rapidamente da arte europeia de vanguarda, aprenderam a psicanálise e plasmaram um tipo ao mesmo tempo local e universal de expressão, reencontrando a influência europeia por um mergulho no detalhe brasileiro. É impressionante a concordância com que um Apollinaire e um Cendrars ressurgem, por exemplo, em Oswald de Andrade (CANDIDO, 1973, p. 12I)7.
\end{abstract}

O próprio Oswald tinha bastante consciência dessas questões, como revela o seguinte testemunho, de Haroldo de Campos: "O primitivismo que na França aparecia como exotismo era para nós, no Brasil, primitivismo mesmo." (CAMPOS, 1972, p. xxxvii) E que também está presente na continuidade da ideia que já citamos, em que Oswald, depois de anunciar que já éramos comunistas, complementa: "Já tínhamos a língua surrealista." (ANDRADE, 1978b, p. I6) Tudo se passa, então, como se fôssemos vanguardistas antes das vanguardas, ou como se, ao menos, já estivéssemos preparados para recebê-las antes de estarem prontas. Insistindo: o legado pré-burguês, contemporizado pela vanguarda, era retirado do registro patrimonialista e nostálgico.

Mas se o primitivismo era mais natural entre nós, não estamos até mesmo além dos pares revolucionários europeus? De fato, uma das consequências dessas po-

\footnotetext{
7 Veja-se como Oswald notará, com sentido diferente, como a própria vida metropolitana daria uma vigência prática aos procedimentos da vanguarda, mas às custas de seu sentido crítico: "As proezas outrora herméticas do surrealismo e do cubismo são hoje menos complexas e obscuras que a contínua fotomontagem processada na cabeça quente do homem cotidiano e normal" (ANDRADE, 1972a, p. 48). Aqui, a constatação é visivelmente decepcionada, mostrando como o capitalismo poderia dar um passo imprevisto de estetização de sua realidade, mas com sinal trocado.
} 
sições é que a própria ideia de transplante, adaptação ou imitação de moldes herdados do além-mar deixa de fazer sentido, ou ao menos sai radicalmente revisada. Não nos internacionalizávamos porque enquadrávamos o dado local à forma importada, dignificando nossa realidade nacional, pois o dado pictórico estava naturalmente no nível do que havia de mais avançado culturalmente na Europa. Lembremos que Oswald (ANDRADE, I978c, p. 7) gostava de descrever a poesia pau-brasil como de exportação, e não de importação, como se o resultado fosse o presente que ela oferece aos olhos do mundo, não o contrário. Daí uma via para a experiência brasileira na cena contemporânea, da qual podíamos tomar parte e tirar proveito num novo nível. Como argumenta Schwarz (1987b, p. 37):

É o primitivismo local que devolverá à cansada cultura europeia o sentido moderno, quer dizer, livre da maceração cristã e do utilitarismo capitalista. A experiência brasileira seria um ponto cardeal diferenciado e com virtualidade utópica no mapa da história contemporânea.

No caso das vanguardas europeias, Oswald achava que a poesia pau-brasil se sairia melhor que elas, já que as depuraria do obscurantismo e do hermetismo que lhes eram congênitos (ANDRADE, 1976, p. 48). Com isso, teríamos lastro para também opinar de volta sobre a cena da atualidade internacional. À distância, as vanguardas interessam menos pelo prestígio estrangeiro do que como fator de descoberta e análise da realidade nacional. O sentido é fomentar a experimentação, o desenvolvimento de formas próprias etc. Conforme o argumento do próprio poeta, que comparava a Semana de Arte Moderna com a Inconfidência Mineira: "Em [19]22, o mesmo contato subversivo com a Europa se estabeleceu para dar força e direção aos ensaios subjetivos nacionais, autorizados agora pela primeira indústria, como o outro o fora pela primeira mineração" (ANDRADE, 1972a, p. 94). Esse alinhamento crítico e criativo com as vanguardas é o que munia Oswald para polemizar com o nacionalismo de Monteiro Lobato, aliás, lembrando que o brasileirismo dos modernistas não seria possível sem o futurismo europeu:

E não percebia você que nós também trazíamos nas nossas canções, por debaixo do futurismo, a dolência e a revolta da terra brasileira. Que as camadas mais profundas, as estratificações mais perdidas da nossa gente iam ser resolvidas por essa "poesia de exportação" que eu proclamava no Pau-brasil (ANDRADE, I972a, p. 4).

Observe-se, aqui, que o que ocorria no plano da literatura parecia funcionar como prenúncio de um processo social mais amplo - do qual as formas literárias fazem parte - , em que o mesmo seria dito e feito a respeito das forças produtivas, também elas a serem devoradas num ritual canibalista, como ocorria no setor parcial das técnicas artísticas. Veja-se, como exemplo, essa formulação, com uma certa ingenuidade que faz sorrir, mas que condensa muito bem o tipo de expectativas que estamos comentando:

Há uma maneira de beber de um trago que se chama à la russe. Os russos souberam industrializar-se à la russe. Por que, num momento em que a fotomontagem triunfa, não poderemos nós realizar, também de um trago, nossa independência técnica, au- 
xiliados pela boa ala americana? E beberemos então à la russe, à saúde de Franklin Delano Roosevelt (ANDRADE, I972a, p. 54).

Esse argumento introduz algo novo e interessante, em que o mesmo raciocínio, feito na esfera particular da arte, poderia ser aplicado ao domínio social mais amplo da produção material em conjunto. Se os métodos vanguardistas, eles próprios tributários das forças produtivas no centro, acomodam-se aqui melhor do que onde nascem, então a indústria, a técnica, os meios de comunicação e de transporte não obedeceriam à mesma lógica? Na equação proposta por Schwarz: inocência brasileira + técnica = utopia. "A ideia é aproveitar o progresso material moderno para saltar da sociedade pré-burguesa diretamente ao paraíso." (SCHWARZ, I987b, p. 37)

É interessante notar como essa concepção ainda sobreviverá um bom tempo entre nós, encontrando ressonância, por exemplo, num texto de Anatol Rosenfeld a respeito da era atômica, o que não deixa de chocar, pois a perspectiva de conflitos nucleares em escala planetária já operava aquela transformação que, nos termos de um Günther Anders (ANDERS, 2007), teria tornado o tempo na Terra em um mero prazo, com o que o nosso horizonte de expectativas, nas observações de Arantes (2014), passava a tender a zero. Pois bem, mesmo diante da possibilidade da catástrofe geral, Rosenfeld argumentava a respeito de uma dialética segundo a qual os países atrasados poderiam ser mais adequados às descobertas dos países adiantados, obedecendo, assim, a uma dialética que seria de ordem geográfica e não temporal.

É por esse motivo que a evolução costuma dar pulos curiosos de um país para outros, uma dialética, por assim dizer, geográfica, transposição do progresso de países adiantados para países mais atrasados, que, aperfeiçoando paulatinamente a sua organização, se veem logo, por sua vez, superados por outro país mais primitivo, devido à maior capacidade deste de ajustar-se às novas invenções entrementes surgidas. Tal fenômeno, ainda em tempos recentes, parece realizar-se no caso da Rússia, há pouco um dos países mais atrasados e que precisamente por isso demonstra ter uma estrutura mais maleável e mais aberta ao progresso técnico (ROSENFELD, 1993, p. 203).
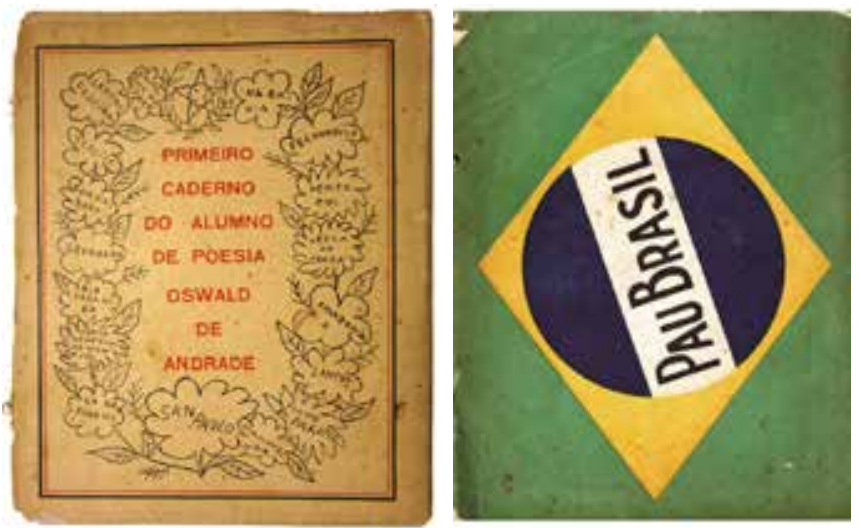

À esq., capa da primeira edição do Primeiro caderno do aluno de poesia, publicada em 1927, dois anos depois da estreia de Oswald como o poeta revolucionário de "Pau-brasil" (centro) e um ano antes do lançamento de "Manifesto antropófago" (dir.)

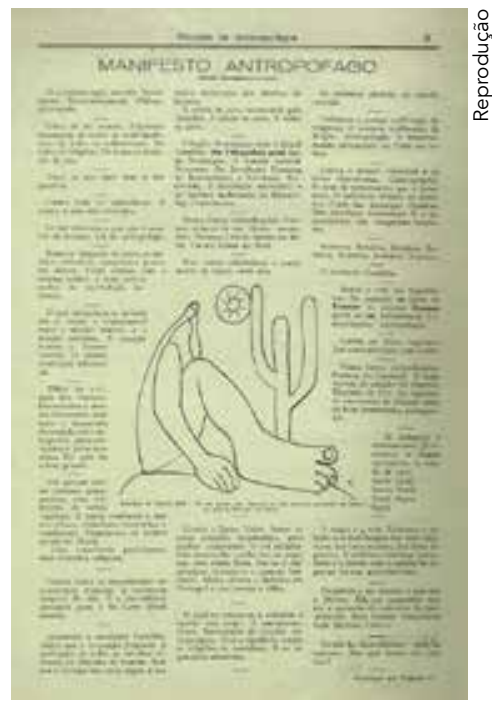


O teor oswaldiano dessas linhas, voluntário ou não, a meu ver salta aos olhos. Em todo caso, a utopia de Oswald era marcada pela maneira como figurava a simultaneidade dos não simultâneos, que, antes de um fato literário, era um dado prático da realidade brasileira. A vantagem dessa posição era não mais se limitar às parcialidades da oscilação entre localismo e cosmopolitismo, os quais, agora, apareciam como contemporâneos um do outro, com efeitos retroativos mútuos. Por um lado, aproveitamento moderno de nosso universo pré-moderno, com vista a um caminho próprio, a uma sociedade nova, que queimaria etapas; por outro, o fulcro folclórico da realidade nacional operando sem saudosismo como filtro e fator de discernimento, com direito a voz no capítulo do cenário internacional, que não ficava incólume. As virtudes desse manejo lúdico de temporalidades distintas, que são também características das figuras do malandro, do samba, do tropicalismo etc., são fáceis de perceber quando divagamos pelos textos de Oswald. Um comparativo interessante estaria na obra de Dorival Caymmi, se quisermos nos beneficiar de um comentário extraordinário de Lorenzo Mammì: suas músicas cantam, sobretudo, uma mobilidade extremamente livre, que caminha entre natureza e cultura, inventando o folclore, mas sem pertencer a seus limites rígidos, beneficiando-se da modernidade como convém, "sem compromisso". Assim, "Caymmi ocupa um lugar intermediário entre história e pré-história, natureza e cultura, onde as seduções do moderno e do arcaico convivem em paz. Desse lugar brota a carga utópica de grande parte da música brasileira” (MAMMÌ, 20I7, p. I6). A similitude dos termos fala por si só.

Depois de descrever esses procedimentos, bem como notar a modernidade que oferecem, Roberto Schwarz passa a expor em que sentido eles também não são isentos. Trata-se, nos termos dele, de "um progressismo acomodatício" (SCHWARZ, I987c, p. 25), cuja "ingenuidade" e "ufanismo" não se podem ignorar (SCHWARZ, I987b, p. 38). Ocorre que Oswald, em parte, nota o que há de disparidade e oposição entre os elementos mais adiantados e os mais atrasados da vida nacional, entre os quais figuram também relações de dominação, mas a satisfação humorística com seus termos os coloca num equilíbrio conformista, que os fixa como tais, gerando um "esvaziamento dos antagonismos" (SCHWARZ, I987c, p. 2I). Isso é uma decorrência do emprego do programa primitivista da vanguarda, a fim de ver a realidade em sua nudez, mas somente parcialmente, pois essa "potência classificatória" rotula objetos "que o procedimento de vanguarda visava liberar" (SCHWARZ, I987c, p. I8). Quer dizer, a mencionada poesia dos fatos torna abstratos os elementos retirados à realidade, enquanto a alegoria dá generalidade quase a-histórica aos elementos com os quais trabalha. As hierarquias brasileiras ficariam mantidas onde estão, ao contrário do desejado pelas vanguardas europeias, preocupadas em implodi-las ${ }^{8}$. É como se houvesse mais satisfação do que crítica em relação às situações nacionais que Oswald formaliza; como se a distância entre a piada e a apologia fosse mais curta do que o esperado. No limite, a informalidade também incorre em ideologia: uma "reverência com o sinal trocado" (SCHWARZ, I987c, p. 27).

8 É interessante como Schwarz faz ecoar as críticas de Lukács (1971a) às alegorias modernistas, mas restringindo seus efeitos negativos a Oswald e salvando Franz Kafka, visado por Lukács, das mesmas críticas. 
Acresce ainda que, contra esse procedimento de Oswald, testemunha a história contemporânea posterior que: a) teria mostrado que nossas singularidades nacionais, longe de serem o caminho próprio para a utopia, são na verdade funcionais para o capitalismo contemporâneo, que as reproduz e delas se beneficia; b) teria, também, dado versões obscuras e autoritárias da matéria-prima com a qual ele trabalha os poemas modernistas, bastando pensar na ditadura instalada em 19649. Mas, para evitar o risco do anacronismo, Schwarz recorre ao fato de que Machado de Assis já dispunha de um senso mais negativo em relação à formação histórica do Brasil, o que dará a tônica de seus romances de maturidade. Seu assunto é, também, a contemporaneidade dos contrários no Brasil, os quais passariam a ser formalizados na figura do narrador, que mimetizaria o comportamento volúvel das classes dominantes entre a norma europeia e seu contrário nacional. Ora, a lição da obra de Machado é que não haveria o que celebrar mais nesse vaivém, pois a "hélice desses mecanismos", diz Schwarz (I987a, p. I24), "empurra em direção — ao nada". Oswald sabia muito bem disso, aliás: "O pessimismo de Machado é um pessimismo de classe. Nele, já existe fixado o germe de toda uma sociedade condenada." (ANDRADE, I972a, p. IOI) Mas isso significa, também, que o modernista estaria dando uma versão otimista e ufanista de um dado prático, contra o qual Machado já cultivava uma posição mais crítica.

Não pretendo discordar das críticas de Schwarz, mas enfocar em outra chave a contemporaneidade da utopia de Oswald perante outras elaborações de esquerda sobre alternativas históricas e as tendências objetivas do capitalismo. Antecipando, digamos que as expectativas que orientam a utopia oswaldiana não tomavam parte num cenário mais universal apenas por atualizar e reformular o programa das vanguardas segundo um contexto local específico, mas porque elas atinavam com reflexões de esquerda, marxistas mais especificamente, a respeito do interesse revolucionário despertado por formas sociais pré-capitalistas que, longe de se dissiparem mesmo nos centros capitalistas europeus do século XX, ofereciam a resistência deliberada contra uma racionalização socioeconômica que lhes rouba a relativa autonomia permitida pelas relações econômicas mais antigas. Trata-se daquelas formas de resistência romântica ao capitalismo, às quais Löwy (2015) dedicou um livro importante, e que desde 1930 eram identificadas como dialética da não contemporaneidade por Bloch, que, aliás, será um dos autores a que iremos recorrer.

O primeiro comparativo que nos interessa, aqui, vem da pena dos próprios Marx e Engels, que em suas intervenções sobre a chamada questão social da Rússia trataram de questões que se aproximam diretamente do que tratamos até aqui. Para introduzi-lo, façamos a seguinte reflexão. Ao menos para uma certa concepção marxista a respeito da sucessão dos modos de produção, essa utopia pau-brasil à qual nos referimos acima não poderia ser mais bisonha. Se ela não tem como pressuposto relações capitalistas de produção bem desenvolvidas, sem as quais não há o nível civilizatório mínimo que criaria as condições materiais para uma sociedade sem classes, então seu objetivo seria, no máximo, o fracasso, e suas ideias seriam utopia pura e simples. Essa

9 Nesse ponto, seria possível estender a Oswald as mesmas dúvidas levantadas por Schwarz (1987d) contra o otimismo de Candido a respeito da malandragem. 


\section{As expectativas que orientam a utopia oswaldiana não tomavam parte num cenário mais universal apenas por atualizar e reformular o programa das vanguardas segundo um contexto local específico, mas porque elas atinavam com reflexões de esquerda, marxistas mais especificamente, a respeito do interesse revolucionário despertado por formas sociais pré-capitalistas}

crítica parte de uma certa concepção etapista do processo histórico, muito comum em países de modernização retardatária, que buscava tomar taticamente o lado da burguesia industrial para desenvolver as condições necessárias para uma revolução socialista.

Como exemplo dessa vertente - e indo direto à nossa comparação —, basta pensar nos autodenominados marxistas russos das décadas de I870 e I880, eles mesmos defrontados com um dilema de ordem semelhante quando da assim chamada questão agrária russa. Se a revolução pressupõe burguesia e proletariado, e se na Rússia o que predomina é a servidão e a propriedade agrária, então o primeiro objetivo do socialismo seria desenvolver o capitalismo, de onde sairia um subproduto típico das periferias do capitalismo, que é um marxismo de corte industrializante. Essa interpretação da parte dos "marxistas" é notificada por uma carta de Vera Ivanovna Zasulitch a Marx, em fevereiro de I88I, em que então aborda o dilema - uma "questão de vida ou morte", segundo ela — da seguinte maneira: a) ou a "comuna rural" se desenvolve pela "via socialista", organizando-se "sobre bases coletivistas"; b) ou "a comuna está destinada a perecer", cabendo ao socialismo decidir em quanto tempo as terras dos camponeses passarão para as mãos da burguesia e "em quantas centenas de anos, talvez, o capitalismo atingirá na Rússia um desenvolvimento comparável ao da Europa Ocidental" (ZASULITCH, 2013, p. 79). Em síntese: queimar etapas com base na propriedade comunal ou passar pelos estágios evolucionistas de desenvolvimento de uma sociedade capitalista? Está claro que os marxistas aos quais Zasulitch se refere se inclinavam pela segunda alternativa, defendendo a obsolescência da propriedade agrária como "a coisa mais indiscutível" defendida pelo "socialismo científico". Segundo Zasulitch (2013, p. 79), os propagadores dessa concepção se defendiam argumentando que não faziam mais do que obedecer a um preceito estabelecido pela obra de Marx: "Foi Marx quem disse isso". 
A fonte dessa tese estaria no capítulo sobre a "acumulação primitiva" do livro I de O Capital. Ali, Marx expõe o processo de formação dos pressupostos históricos que deram origem ao desenvolvimento capitalista na Europa Ocidental, entre os quais consta a abolição da propriedade privada agrária e sua transformação em propriedade privada burguesa. Um processo "negativo", mas que ao mesmo tempo criaria as condições históricas necessárias para que o socialismo, por sua vez, negasse o capitalismo, para a criação de uma sociedade de tipo superior. Marx descreve esse processo como uma "negação da negação". Ora, o que os tais "marxistas" russos reconheceram aí é um modelo abstrato de como a revolução socialista deveria ocorrer em todas e quaisquer situações históricas. E se na Rússia ainda predominava a propriedade agrária camponesa, para estar à altura do socialismo seria necessário percorrer o mesmo trajeto supostamente exposto por Marx no capítulo mencionado. Veja-se que são dilemas que também fizeram parte do marxismo no Brasil ${ }^{10}$.

Marx já havia se defrontado com essa distorção quatro anos antes, ao responder ao artigo "Karl Marx diante do tribunal do sr. Jukovski”, publicada na revista Otechestvenye Zapiski, em I877, e assinado por Nicolai C. Michailovski. O referente ainda é o capítulo sobre a "acumulação primitiva”, do qual Michailovski extrai os seguintes argumentos, segundo Marx:

Ora, como meu crítico aplicou esse esboço histórico à Rússia? Tão somente assim:
se a Rússia tende a tornar-se uma nação capitalista a exemplo das nações da Europa
Ocidental - e durante os últimos anos ela se esforçou muito nesse sentido -, não
será bem-sucedida sem ter transformado, de antemão, uma boa parte de seus campo-
neses em proletários; e, depois disso, uma vez levada ao âmago do regime capitalista,
terá de suportar suas leis impiedosas como os demais povos profanos. Isso é tudo!
Mas isso é pouco para o meu crítico. Ele ainda tem necessidade de metamorfosear to-
talmente o meu esquema histórico da gênese do capitalismo na Europa Ocidental em
uma teoria histórico-filosófica do curso geral fatalmente imposto a todos os povos,
independentemente das circunstâncias históricas nas quais eles se encontrem, para
acabar chegando à formação econômica que assegura, com o maior impulso possível
das forças produtivas do trabalho social, o desenvolvimento mais integral possível de
cada produtor individual (MARX, 20I3a, p. 68).

Já veremos quais argumentos Marx empregará para deslindar esses equívocos. O que se nota, por enquanto, é que se trata de um erro muito familiar, de tomar certos esquemas históricos desenvolvidos por Marx para momentos específicos do desenvolvimento histórico e convertê-los em modelo geral de como as etapas devem se suceder em todas e quaisquer circunstâncias. Para efeito de contraste, note-se que o próprio Engels, justamente em sua intervenção no mesmo debate russo, não deixou a fornecer argumentos a favor da visão etapista. O contexto, no caso, é a resposta de Engels a uma carta pública de Tkatchov a ele dirigida. Tkatchov era um dos narodniks que herdaram a maneira pela qual Herzen encarava a questão da comuna agrária na Rússia, que, por sua vez, se

10 Para uma síntese histórica de como os problemas do "dualismo", do "feudalismo" e do "etapismo" tomaram feição no marxismo brasileiro, ver Dória (1998). 
inspirava no livro do alemão Haxthausen, Estudos sobre as condições internas, a vida populare particularmente as instituições rurais da Rússia, de I847, no qual notava o caráter comunitário e solidário da propriedade camponesa na Rússia, que, para Herzen, seria a base do socialismo russo. Herdeiro dessa interpretação, Tkatchov argumenta que, na Rússia, onde não há burguesia, onde "o poder do capital ainda é embrionário" (TKATCHOV apud ENGELS, 20I3a, p. 37) e o povo está na maior parte "impregnado das posses comuns", as vantagens para o futuro socialismo são maiores que na Europa Ocidental: "nosso povo", argumenta Tkatchov, "está muito mais próximo do socialismo do que os povos da Europa Ocidental, mesmo que estes sejam mais cultos" (TKATCHOV apud ENGELS, 2013a, p. 48-9). Argumentava, portanto, semelhantemente a Oswald, que dizia que já tínhamos o comunismo.

Engels responderá com um argumento que pode dar razão a equívocos etapistas. Segundo ele, Tkatchov no fundo não entendeu nada a respeito do socialismo, que passa a ser descrito da seguinte maneira:

A revolução almejada pelo socialismo moderno é, sucintamente, a vitória do proletariado contra a burguesia e a reorganização da sociedade mediante a anulação das diferenças de classes. Para tanto, é preciso que haja não só um proletariado capaz de realizar essa revolução, mas também uma burguesia, em cujas mãos as forças produtivas da sociedade se desenvolveram a ponto de permitir a anulação definitiva das diferenças de classe. Entre os selvagens e semisselvagens frequentemente também não há diferenças de classe, e todos os povos passaram por tal situação. A ideia de restaurá-la sequer pode nos ocorrer, por dela decorrem necessariamente, com o desenvolvimento das forças produtivas da sociedade, as diferenças de classe. Somente em certo estágio do desenvolvimento das forças produtivas da sociedade, que até para os tempos atuais é bastante elevado, torna-se possível aumentar a produção a um nível em que a eliminação das diferenças de classe seja um verdadeiro progresso e possa ser duradoura, sem acarretar uma paralisação ou mesmo um retrocesso no modo de produção da sociedade. Porém, as forças produtivas só chegaram a esse grau de desenvolvimento pelas mãos da burguesia. Sendo assim, a burguesia, também nesse aspecto, é uma precondição tão necessária da revolução socialista quanto o próprio proletariado. Portanto, um homem capaz de dizer que seria mais fácil realizar essa revolução em certo país porque este não tem proletariado nem burguesia só prova, com isso, que ainda tem de aprender o bê-á-bá do socialismo (ENGELS, 20ı3a, p. 37).

O tom professoral da conclusão não deixa enganar. Engels arma uma resposta mais em linha com os "marxistas" russos, para os quais não há socialismo na Rússia se antes não houver capitalismo, do que com a reação de Marx contra eles. Se Tkatchov não entendeu o básico do socialismo, é porque ele não compreendeu que as forças produtivas necessárias para a transição ao socialismo só são desenvolvidas sob as mãos da burguesia, que primeiro deveria ser fortalecida na Rússia. O esquema não tolera particularidades históricas, que encontrariam vias próprias para o socialismo: em todo lugar, as etapas devem sempre ser basicamente as mesmas. O caráter ingênuo e pouco realista das ideias de Tkatchov são dignas de nota, como lembra Löwy, mas é igualmente notável "o forte viés economicista" da resposta de Engels (LÖWY, 2013, p. Io). 
Quando passamos ao detalhe dos argumentos de Marx a respeito da questão, notamos as diferenças no modo de encarar o problema, o que parece aproximá-lo mais da concepção criticada por Engels - sendo o nosso interesse ver como suas reflexões se aproximam de maneira surpreendente de concepções defendidas por Oswald no Brasil. Na carta de I877, que já citamos, Marx reconhece a chance história única dada pela particularidade da situação da Rússia: "Se a Rússia prosseguir no rumo tomado depois de I86I, ela perderá a melhor chance que a história já ofereceu a um povo, para, em vez disso, suportar todas as vicissitudes fatais do regime capitalista" (MARX, 20I3a, p. 66). Como lembra Wada (I983, p. 58, tradução nossa), "o rumo tomado depois de I86I" não é outra coisa que o desenvolvimento capitalista. Mas em que consiste, mais especificamente, essa chance?

É nos esboços da carta em resposta a Zasulitch que o argumento geral está mais documentado. A versão final da carta, tal como foi enviada a Zusalitch, é muito mais sucinta e se resume a mostrar que, no capítulo sobre a "acumulação primitiva", Marx estava preocupado com um caso particular de desenvolvimento histórico, descrito pela passagem de uma forma de propriedade privada a outra, o que por si só já difere do caso da Rússia, onde a atual propriedade agrária é posse coletiva e não particular dos camponeses ${ }^{\text {II }}$. Na conclusão, são mencionadas rapidamente as vantagens históricas dessa formação social: a propriedade comunal é a "alavanca da regeneração social da Rússia", conquanto ele combata as "influências deletérias que a assaltam de todos lados" e assim se assegurem "condições normais de um desenvolvimento espontâneo" (MARX, 20I3b, p. II5). Nos "esboços”, Marx esmiúça mais esse ponto. Segundo ele, a propriedade comunal russa está atravessada por um "dualismo", em que coexistem tanto modos coletivos de divisão da propriedade como modos individuais de cultivo e usufruto do solo. Tal "dualismo" dotava a comuna agrícola de uma "vida vigorosa” (MARX, 20I3b, p. IIo), que permitia uma forma de propriedade comunal sem as relações estreitas de parentesco que caracterizam a propriedade comum do solo. Marx destaca sobretudo o impulso para o desenvolvimento da individualidade, impossível em relações arcaicas firmadas por laços de sangue.

A dualidade é a vantagem e também a possível ruína da comuna russa. Se o lado individualista prevalecer, o aspecto comunalista seria prejudicado e a vantagem histórica única dessa formação social seria perdida. Como impedir que isso aconteça? Nesse ponto, Marx lança mão de um argumento que, caso não seja forçado, guarda proximidades com a utopia antropofágica, o que talvez denote um aspecto comum para as periferias do capitalismo. É que, não estando isolada do mundo, a Rússia é contemporânea do desenvolvimento do capitalismo do Ocidente, cujos resultados ela pode aproveitar sem ter de se submeter às regressões particulares que a formação do capitalismo carrega consigo. Num trecho que aparece reescrito de diferentes modos nos esboços, mas com a mesma ideia geral, Marx argumenta:

11 Apesar disso, Shanin (1983) não deixa de notar uma relativa mudança de perspectiva nas obras do que ele chama de "Marx tardio" a partir da década de 1870, quando Marx se defronta mais com questões levantadas pelo desenvolvimento heterogêneo que o capitalismo vai assumindo em diferentes países. Wada (1983) documenta com detalhe essa mudança, revelando como o contato com intelectuais russos foi fundamental para tanto. 


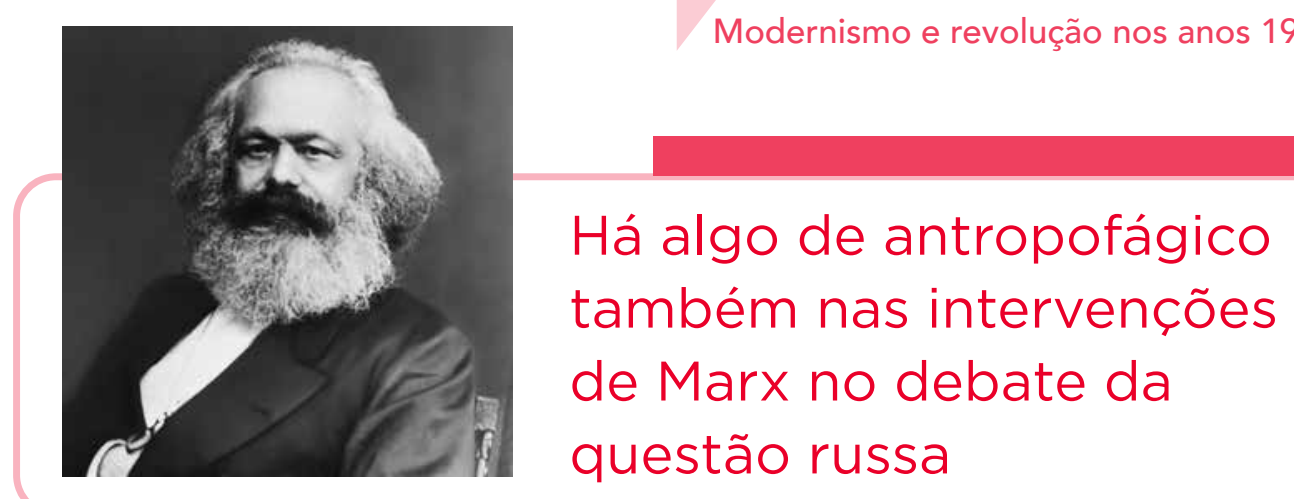

E a situação histórica da "comuna rural" russa é sem igual! Ela é a única na Europa que se mantém não como ruína esparsa, a exemplo das miniaturas raras e curiosas na condição de tipo arcaico que ainda se encontravam havia pouco tempo no Ocidente, mas como forma quase predominante da vida popular e espalhada por todo um imenso império. Tendo ela na propriedade comum do solo a base da apropriação coletiva, o seu ambiente histórico, a contemporaneidade da produção capitalista, disponibiliza-lhe já prontas todas as condições materiais do trabalho comum em larga escala. Ela é capaz, portanto, de incorporar as conquistas positivas produzidas pelo sistema capitalista sem passar por suas "forcas caudinas". Ela pode substituir gradualmente a agricultura parceleira pela agricultura extensiva com o auxílio de máquinas, a que convida a configuração física da terra russa. Ela pode, portanto, tornar-se o ponto de partida direto do sistema econômico para o qual tende a sociedade moderna e trocar de pele sem ter de cometer suicídio (MARX, 20I3b, p. IOo).

Numa outra formulação Marx fala da situação particular da Rússia comparada a outras comunidades primitivas, pois, se nela vigoram elementos de uma sociedade de tipo arcaico, ela também "existe em um contexto moderno", sendo contemporânea de uma "cultura superior", ligada "a um mercado mundial" capitalista (MARX, 20I3b, p. I07). Ela vive em dois tempos, obedecendo a essa simultaneidade dos não contemporâneos, o que a situa na condição singular de se beneficiar das vantagens de ambos os componentes. Variemos a fórmula de Oswald e digamos que estamos às voltas também com as virtudes da Rússia feudal-burguesa. Está aí sua chance histórica única para que uma forma supostamente "arcaica" de propriedade seja na verdade a senha para uma transição sem paralelo ao socialismo, que poderia queimar etapas e se beneficiar dos ganhos civilizatórios do capital sem ter de passar pelas etapas de sua formação. Por isso, diz Marx (2013b, p. 9I), "não há por que se deixar atemorizar pela palavra arcaico". Ele pensa, entre outros aspectos, na cooperação já existente entre trabalhadores na propriedade agrária, que facilitaria a transição para um trabalho cooperativo comunista. Trata-se de um exemplo notável de reflexão materialista sobre as possíveis vantagens que elementos pré-capitalistas podem oferecer para uma sociedade pós-capitalista.

Com isso, é a própria noção de força produtiva que deve ser repensada. Muito em linha com as reflexões de $A$ ideologia alema $\tilde{a}^{12}$ sobre as consequências planetárias 
do desenvolvimento da máquina a vapor, que faz o capitalismo inaugurar a chamada história universal, as forças produtivas deixam de ser aqui aproveitáveis somente sob a forma de produção endógena, auspiciada por uma burguesia nacional ${ }^{13}$ — o que é uma reflexão que certamente interessaria ao socialismo no Brasil ${ }^{14}$. Marx podia contar com a prova de que a Rússia já se beneficiava de descobertas técnicas capitalistas sem por isso ter de passar pelo período de desenvolvimento industrial: "Para explorar as máquinas, os barcos a vapor, as ferrovias, a Rússia foi forçada, a exemplo do Ocidente, a passar por um longo período de incubação da indústria mecânica?" (MARX, 20I3b, p. 90). Essa reflexão desconecta o emprego de tecnologias modernas de sua origem no modo de produção capitalista e sugere à imaginação as vantagens relativas que podem ter países que não passaram e não precisariam passar pelas degradações típicas do desenvolvimento capitalista.

Mas não é só que a comuna russa seja contemporânea do capital ocidental, e sim que ela seja contemporânea da crise do capitalismo no centro. Quer dizer, ela se beneficia internacionalmente de um contexto em que o próprio capitalismo passa a lutar "contra as massas trabalhadoras, contra a ciência, contra as próprias forças produtivas que engendra", o que Marx considera uma "crise que terminará com a sua eliminação, com o retorno das sociedades modernas a uma forma superior de um tipo arcaico da propriedade e da produção coletivas" (MARX, 20I3b, p. 95-96). Essa é a melhor prova "de que esse desenvolvimento da 'comuna rural' responde à corrente histórica de nossa época", a saber: "a crise fatal sofrida pela produção capitalista nos países europeus e norte-americanos” (MARX, 20I3b, p. 99). Isso implica: a) que as forças produtivas a serem aproveitadas na periferia já estão em franca contradição com as relações de produção no centro; b) que o salto russo em direção ao socialismo é contemporâneo ao declínio do capitalismo e sua superação por uma sociedade superior no Ocidente. Daí a paradoxal atualidade da não contemporaneidade da Rússia, cujo atraso relativo a converte em símbolo da sociedade vindoura. É claro que isso implica que, para o prognóstico dar certo, é preciso que haja uma revolução na Rússia e, a partir daí, uma revolução no Ocidente que gere um reforço mútuo. No extraordinário prefácio à edição russa do Manifesto comunista, de I882, Marx e Engels reconhecem na Rússia o possível "sinal" para uma revolução no centro. Essa seria a única possibilidade de evitar a necessidade de passar pelos mesmos percursos realizados no Ocidente: "Se a revolução russa constituir-se no sinal para a revolução proletária no Ocidente, de modo que uma complemente a outra, a atual propriedade comum da terra na Rússia poderá servir de ponto de partida para uma evolução comunista”

13 Engels continuará pensando diferente, mesmo depois desses textos de Marx.

14 E à América Latina, também. Como lembra Löwy, Mariátegui tinha ideias semelhantes para o socialismo na América Latina, como se nota neste trecho retirado das teses enviadas por ele ao $1^{\circ}$ Congresso dos Partidos Comunistas da América Latina: "Acreditamos que, entre os povos 'atrasados', nenhum outro como o indígena arcaico reúne condições tão favoráveis para que o comunismo agrário primitivo, subexistente [sic] em estruturas concretas e em profundo espírito coletivista, se transforme, sob a hegemonia da classe proletária, em uma das bases mais sólidas da sociedade coletivista preconizada pelo comunismo marxista." (MARIÁTEGUI apud LÖWY, 2013, p. 14) 
(MARX; ENGELS, 2013, p. I25) ${ }^{15}$. O teor premonitório dessas linhas fala por si só.

Sem que Oswald tivesse noção nenhuma dessas páginas, é notável como sua visão utópica para o Brasil partia de convicções muito semelhantes. Se não for forçar a nota, digamos que há algo de antropofágico também nas intervenções de Marx no debate da questão russa. Se retornamos aos trechos em que Oswald sustentava que, no Brasil, havia um regime de cooperação ainda não deturpado pela técnica, o que nos permitiria aproveitar a indústria estadunidense à la russe, como dizia ele, então notamos uma argumentação muito semelhante. Em ambos os casos, a simultaneidade entre o arcaico e o moderno, que o desenvolvimento desigual e combinado do capitalismo havia difundido na periferia, oferecia oportunidades históricas únicas para um horizonte de supressão do capital, sem a necessidade de enfrentar as cargas do desenvolvimento de um regime burguês, tal como vigorava nos EUA e na Europa Ocidental ${ }^{16}$. Beneficiado pelas vanguardas artísticas, Oswald dispunha de um meio bastante adequado para montar essas combinações contraintuitivas e dar-lhes um tom favorável. Tanto na Rússia quanto no Brasil, a persistência de formas tidas como arcaicas era encarada como problema nacional, mas enquadrada segundo uma perspectiva contemporânea - o que fazia a própria modernidade, por sua vez, ser figurada com um crivo próprio e original. A comparação entre ambos os casos faz pensar também no lado objetivo de que talvez se trate de um certo elemento comum e está-

15 A perspectiva de Engels, 12 anos depois, em 1894, ainda continuará diferente da de Marx, e em grande medida continua semelhante à concepção exposta em 1875. Lá, Engels defendia a tese de que a propriedade agrária só poderia oferecer a passagem a uma forma superior sem necessidade de percorrer os estágios de desenvolvimento da propriedade burguesa se, "na Europa Ocidental, uma revolução for vitoriosa ainda antes da degradação total da propriedade comunal" (ENGELS, 2013a, p. 53). Por si só, esse trecho já é diferente da ideia exposta no prefácio citado, de que é antes a revolução russa que deve dar o sinal para a revolução no Ocidente. Em 1894, Engels sustentará a visão antiga: "A partir disso, já se depreende que a iniciativa para uma eventual reconfiguração da comuna russa não poderá partir dela mesma, mas única e exclusivamente dos proletários industriais do Ocidente. A vitória do proletariado europeu ocidental contra a burguesia e as substituições a ela associadas da produção capitalista pela produção socialmente conduzida constituem as precondições necessárias para alçar a comuna russa ao mesmo estágio." (ENGELS, 2013b, p. 132) Sabemos que, naquele momento, havia grande expectativa sobre a possibilidade de uma revolução na Europa Ocidental, mais precisamente na Alemanha, e algo desse ânimo pode ter influenciado essas afirmações de Engels, que, de resto, parecem dar razão a uma visão mais economicista e etapista do caminho para o socialismo, visão esta que Löwy (2013, p. 16) considera inclusive eurocêntrica.

16 A comparação com o caso russo é possível em mais de um sentido, como é indicado, por exemplo, por um argumento de Roberto Schwarz, em "As ideias fora do lugar", aqui centrado mais na espécie de privilégio crítico negativo fornecido pela experiência periférica com as instituições vindas das sociedades burguesas. Como se sabe, longe da origem, elas funcionam de modo diferente, com sinal trocado, fundindose com aquilo que abominam, no caso, a escravidão e o regime servil. Para os grandes mestres da literatura desse momento, tratava-se de explorar esse resultado, mostrando que não se tratava de um desvio, mas de uma experiência que revelava verdades internas sobre a sociedade burguesa, vistas somente graças a esse deslocamento. Assim, ele escreve: "Também na Rússia a modernidade se perdia na imensidão do território e da inércia social, entrava em choque com a questão servil e com seus restos -, choque experimentado como inferioridade e vergonha nacional por muitos, sem prejuízo de dar a outros um critério para medir o desvario do progressismo e do individualismo que o Ocidente impunha e impõe ao mundo. Na exacerbação desse confronto, em que o progresso é uma desgraça, e o atraso, uma vergonha, está uma das raízes profundas da literatura russa. Sem forçar em demasia uma comparação desigual, há em Machado — pelas razões que procurei apontar — um veio semelhante, algo de Gógol, Dostoiévski, Gontcharov, Tchekhov, e de outros talvez, que não conheço. Em suma, a própria desqualificação do pensamento entre nós, que tão amargamente sentíamos, e que ainda hoje asfixia o estudioso do nosso século XIX, era uma ponta, um ponto nevrálgico por onde passa e se revela a história mundial." (SCHWARZ, 2012, p. 28-29) A comparação feita por Oswald com a questão da propriedade comunal russa apresenta elaborações mais otimistas a respeito desse quadro. 
vel característico de industrializações retardatárias. Oswald, no caso, já se encontrava num momento seguinte, em que a guerra, o aprofundamento da crise do capitalismo e a Revolução Russa criavam um clima internacional ainda mais favorável à esperança de um aproveitamento moderno e atualizado de nossas particularidades nacionais.

Em ambos os casos, o caminho para formas sociais superiores não é ditado por esquemas abstratos, mas tem apoio na reflexão crítica sobre particularidades locais, que deveriam encontrar caminhos próprios segundo seus pressupostos singulares. Ambos tampouco eliminam o aproveitamento de elementos presentes nas sociedades burguesas, que seriam assimilados à distância, segundo outras necessidades, e sem as degradações típicas de sua origem. O clima geral é de busca por atalhos, o que põe em dúvida as noções (mesmo de esquerda) de progresso e de evolução histórica.

Vamos seguir nesse fio comparatista e avançar um pouco em direção a um livro extraordinário que é Heritage of our times (herança de nosso tempo), de Ernst Bloch, também ele muito em sintonia com coisas que estamos estudando aqui. Publicado na década de 1930, tem como um de seus temas centrais o que Bloch chama de "dialética da não contemporaneidade" - expressão que já empregamos livremente aqui —, cujo objetivo converge bem para as reflexões que vimos acima. Não à toa, trata-se também de uma reflexão socialista, com sensibilidade para particularidades históricas únicas, a respeito de uma realidade muito específica gerada por um caso também de industrialização retardatária. É claro que a Alemanha de então já era um país muito mais industrializado em seus centros que Brasil e Rússia, com um movimento operário já mais consolidado, além de ter diante de si o combate contra o nazifascismo. Mas nem por isso deixa de ser um caso semelhante, e talvez até mesmo exemplar da necessidade de ganhar para a revolução e para a sociedade do futuro os motivos de um passado pré-moderno, não assimilados pela contemporaneidade do capital, e que por isso mesmo podem ter voz no capítulo. É interessante passar a Bloch, uma vez que, em relação aos dois casos antecedentes, ele opera algo como um movimento de síntese: enquanto Marx foca o argumento no regime de propriedade e Oswald se concentra mais nos elementos culturais do legado pré-capitalista, Bloch oferece uma combinação de ambas as dimensões, pois se trata de ganhar para a revolução tanto aspectos da reprodução material dos camponeses alemães quanto sua dimensão ideológica e cultural.

O ponto de partida do livro é a constatação de que "nem todas as pessoas vivem no mesmo Agora" (BLOCH, I99I, p. 97, tradução nossa). Trata-se, antes de mais nada, de um fato a ser constatado e enquadrado em sua objetividade própria. "Impulsos e reservas de tempos e superestruturas pré-capitalistas estão então em operação, não contemporaneidades genuínas, portanto, que uma classe em declínio revive ou que causa o reavivamento de sua consciência." (BLOCH, I99I, p. I06, tradução nossa) Bloch refere-se, aqui, sobretudo aos camponeses alemães e à classe média em declínio, ambos os grupos ligados a modos de vida incompatíveis com o atual estágio de racionalização capitalista, contra a qual, portanto, o relativo "atraso" oferece algo como um obstáculo. O registro não é apenas de mera diferença temporal, mas de contradição: "Eles tampouco florescem na obscuridade como no passado, mas contradizem o Agora." (BLOCH, I99I, p. 97, tradução nossa) 


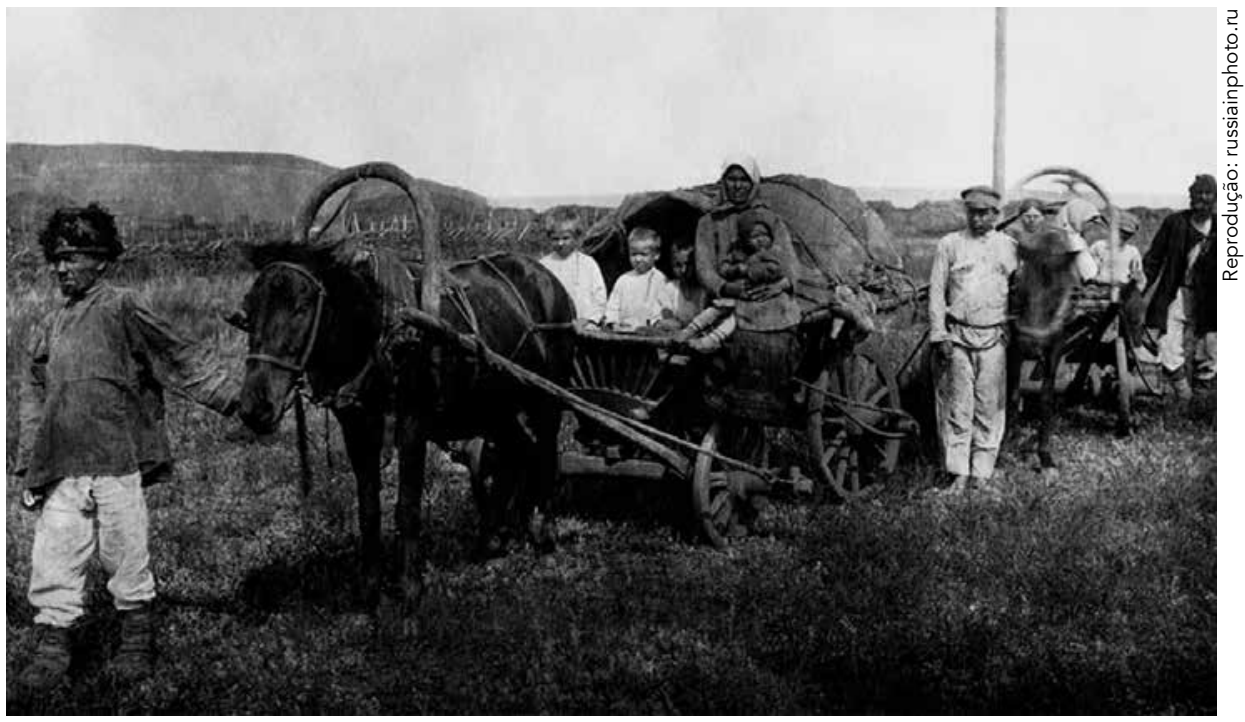

Família camponesa na Rússia do século XIX

A atenção vai principalmente para os camponeses, que obedecem a essa dialética da não contemporaneidade tanto no regime de produção quanto nas formas culturais e ideológicas em que vivem. Entre eles, predomina a propriedade coletiva e não privada do solo, além de uma relação mais mítica e cíclica com a terra, incompatível com o princípio de racionalização. Assim,

econômica e ideologicamente, os camponeses têm, em meio ao rápido século capitalista, uma posição mais antiga, não importa o quanto o capitalismo também tenha adaptado a propriedade agrária, um elemento pré-capitalista, para seus próprios fins, não importa o quanto tenha capitalizado o campesinato e o provido com seus produtos, não importa o quanto o último vilarejo esteja conectado pela ratio ao juste milieu. Os camponeses, mesmo assim, retêm um resíduo torto, sentem-se representados antes pelos estados senhoriais do que pelos trabalhadores na estranha cidade (BLOCH, I99I, p. IOI, tradução nossa).

Trata-se de olhar a questão tanto em seu aspecto subjetivo quanto objetivo: Enquanto um mero não desejo abafado pelo Agora, esse elemento contraditório é subjetivamente não contemporâneo e, enquanto uma reminiscência existente de tempos anteriores no presente, objetivamente não contemporâneo. O elemento subjetivamente não contemporâneo, depois de ter sido por muito tempo apenas amargura, aparece hoje como raiva acumulada. [...] Correspondente a isso está o elemento objetivamente não contemporâneo enquanto influência contínua de circunstâncias e formas de produção antigas, não importa o quão atravessadas tenham sido, assim como de antigas superestruturas. O elemento objetivamente não contemporâneo é aquele que está distante e alheio ao presente; ele acolhe então as reminiscências em declínio e, sobretudo, o passado não restaurado que ainda não está "resolvido" em termos capitalistas. A contradição subjetivamente não contemporânea ativa a objetivamente não contemporânea, fazendo ambas as contradições se encontrarem, a torta e rebelde da 
raiva acumulada e a objetivamente alheia do ser e da consciência sobreviventes (BLOCH, I99I, p. I08-I09, tradução nossa).

Tais argumentos estão muito centrados na crítica do capitalismo enquanto processo de racionalização, que certamente faz ecoar as investigações dialéticas do Lukács de História e consciência de classe. Uma vez definido o fetiche da mercadoria como pedra angular para uma crítica tanto das formas objetivas do capitalismo quanto das formas de subjetividade a ele correspondentes, Lukács abriu um caminho para críticas do capitalismo interessadas principalmente nas regressões subjetivas e culturais que seus imperativos exigem. No entanto, para Bloch a resistência a esse estado de coisas não vem mais somente do "ponto de vista do proletariado" enquanto "sujeito-objeto idêntico da história", até porque é possível que as regressões da reificação alcancem também o âmago da consciência da classe trabalhadora, mas daqueles que ficaram de fora do processo de reificação, que ainda guardam reminiscências materiais e culturais anteriores ao fetiche da mercadoria, então vistas como uma possibilidade de rebelião contra o Agora capitalista e a favor de uma possível sociedade pós-mercadoria futura. É no campesinato que ainda se encontra o resíduo da "vida não destruída pelo capital" (BLOCH, I99I, p. III, tradução nossa), que interessa reproduzir num futuro revolucionado. Em outras palavras, da perspectiva de Bloch trata-se não só de entender por que existem estratos sociais que ainda não entraram no regime capitalista da vida, mas por que eles não o querem fazer.

Note-se que, embora Bloch reconheça que a contradição não contemporânea, que é explosiva, não esteja ao lado do proletariado nem se encontre no campo de batalha entre trabalhadores e burguesia, sua força rebelde só pode ser garantida se ocorrer simultaneamente a uma contradição contemporânea, que é a do proletariado no Agora capitalista, cujo objeto é o futuro, e não o passado restaurado. Enquanto a não contemporaneidade se apoia em técnicas e ideologias passadas, a contradição contemporânea tem seu núcleo na contradição entre forças produtivas geradas dentro do capitalismo e suas relações de produção. Ambas as contradições partilham da mesma matéria - a oposição ao capitalismo - , mas com perspectivas diferentes, de forma que caberia unir esforços em vista de um objetivo comum. Veja-se que ao dar dignidade revolucionária ao anticapitalismo como que espontâneo do campesinato, Bloch assume uma posição próxima aos narodniks russos, opondo-se ao esquema evolutivo e etapista segundo o qual seria necessário proletarizar os camponeses para ganhá-los para a causa da revolução, vendo antes em seu próprio elemento arcaico o índex de um futuro pós-capitalista sem o interregno burguês.

Seguindo nas aproximações com os casos anteriores que analisamos, veja-se que a matéria de Bloch é também aquela dualidade de um país que coloca lado a lado elementos contemporâneos e burgueses com elementos arcaicos e pré-modernos. Não se trata, portanto, de um país ainda agrário isolado da cena contemporânea, tampouco de um país que assumiu a modernidade em sua forma "clássica", como a França e a Inglaterra, e sim de um caso daquela "simultaneidade dos não simultâneos”, que, na Rússia como no Brasil, alimentava a esperança de uma via própria e não 
burguesa para uma sociedade de tipo superior. Assim como no caso da Rússia e do Brasil, Bloch reconhece isso como um caso particular da Alemanha - "o país clássico da não contemporaneidade" (BLOCH, I99I, p. I06, tradução nossa) —, que realizou muito tarde sua revolução burguesa, o que retardou a integração da vida agrária ao poder econômico do capital. É mais um caso do "ritmo desigual de desenvolvimento" do capitalismo, que também aqui não é encarado como mera desvantagem ou como problema a ser resolvido segundo a régua do progresso, mas como possibilidade de contradição e resistência. Assim como Marx teve de encarar a necessidade de reconhecer as formas heterogêneas que o capitalismo pode assumir fora do centro, Bloch também reformula a própria noção de capitalismo. Este é agora

entidade polirrítmica e multiespacial, com vários cantos não dominados e, no entanto, mesmo assim não revelados nem resolvidos. Hoje, nem mesmo as infraestruturas econômicas desses cantos, i.e., as formas obsoletas de produção e troca, foram ultrapassadas, muito menos suas superestruturas ideológicas, muito menos os conteúdos autênticos da irratio ainda não definida. É justamente isso o que fornece o material para o anticapitalismo romântico desses estratos, em especial para o tipo realista-romântico (BLOCH, I991, p. 62, tradução nossa).

Particularmente nesse caso, a questão ganha contornos mais urgentes, não apenas porque, como na Rússia, o declínio da comuna agrária acarretaria a perda de uma chance histórica única, mas porque, na Alemanha das décadas de I920 e I930, a energia inconformista e rebelde da não contemporaneidade estava sendo mobilizada pelo nazismo, que entre outras coisas dispôs de estratégias para mobilizar a insatisfação e impulsos contra a modernização para as causas da reação. Contra o que Bloch clama: "Está na hora de arrancar essas armas das mãos da reação. Hora particularmente de mobilizar contradições dos estratos não contemporâneos contra o capitalismo sob direção socialista." (BLOCH, I99I, p. 2, tradução nossa) Isso confere uma dramaticidade e urgência próprias ao caso alemão, que embora possa ter paralelo na leitura que o integralismo e o verde-amarelismo faziam do problema no Brasil, difere bastante da solução piadista e bem-humorada que Oswald encaminhava. É surpreendente ver como Bloch sustentava um certo otimismo e confiança na combinação entre as duas dialéticas para impedir o nazismo até mesmo em meados da década de 1930.

Um último aspecto que aproxima mais Bloch de Oswald do que dos russos, até por uma diferença no tempo, é que em ambos a problemática do país atravessado por temporalidades não contemporâneas afinava com um senso modernista em dia com as vanguardas artísticas de então. Bloch manifesta explicitamente seu interesse pelas técnicas de montagem, pelo expressionismo e pelo surrealismo ao longo do livro. É de se esperar que, quando se trata de olhar para uma perspectiva multifacetada, voltada à simultaneidade de estruturas diferentes, a montagem e o surrealismo venham a calhar. Mas é sobretudo no expressionismo que Bloch alinha a modernidade estética com a perspectiva da não contemporaneidade - lembrando aliás que ele foi 
um dos protagonistas no debate de esquerda a respeito do expressionismo alemão ${ }^{17}$. O destaque vai para o anticapitalismo do expressionismo, que dependia da combinação entre "sombras objetivamente arcaicas" e "luzes revolucionárias"; entre os "lados sombrios" do submundo de uma subjetividade indomada e os "lados iluminados" do futuro (BLOCH, I99I, p. 236). Trata-se de uma integração do "não-mais-consciente" ao "ainda-não-consciente", que servia a uma montagem com partes retiradas de diferentes lugares da face do mundo (BLOCH, I99I, p. 238). Bloch destaca repetidamente que a obra expressionista é composta de "imagens arcaicas" junto com uma "imaginação revolucionária" (BLOCH, I99I, p. 245). Nessa linha, era natural que pintores de países com independência recente, como Tchecoslováquia e Iugoslávia, encontrassem no expressionismo "uma forma de expressão que estava significativamente mais próxima de seu folclore nativo do que estilos artísticos anteriores" (BLOCH, I99I, p. 250, tradução nossa). Assim como para Oswald o programa primitivista das vanguardas parecia mais natural na periferia da Europa do que em seu centro.

Vamos encontrar o caminho de volta para Oswald e o Brasil. Claramente inspirado pela perspectiva de Bloch, Fredric Jameson, agora com horizonte no debate do pós-modernismo, reconheceu a simultaneidade dos não contemporâneos não como a marca específica dos movimentos artísticos em países relativamente atrasados, mas como a do modernismo estético em geral:
A arte moderna, a esse respeito, retirava seu poder e suas possibilidades por ser um remanso e um adiamento arcaico no interior de uma economia em modernização: ela glorificava, celebrava e dramatizava formas antigas de produção individual que o novo modo de produção, em outros lugares, estava a ponto de deslocar e apagar. A produção estética oferecia então a visão utópica de uma produção mais humana em geral; e no mundo do estágio monopolista do capitalismo, ela exercia um fascínio por meio da imagem que oferecia de uma transformação utópica da vida humana. [...] O Modernismo, portanto, deve ser visto como correspondendo unicamente a um momento desigual do desenvolvimento social, ou do que Ernst Bloch chamou de "si- multaneidade do não simultâneo", a "sincronia do não sincrônico" (Gleicheitigkeit des Ungleichzeitigen): a coexistência de realidades de momentos radicalmente diferentes da história - artesãos ao lado dos grandes cartéis, terras camponesas com as fábricas de Krupp ou a planta de Ford na distância (JAMESON, I99I, p. 307, tradução nossa).

Num texto um pouco mais recente, o autor retoma o argumento para explicar o grande fascínio do Modernismo pelo tempo (em contraste com o privilégio pós-modernista do espaço). Segundo ele, a grande fixação modernista pela temática (que vai avançar até mesmo em direção à filosofia, como em Bergson e Heidegger) se deve justamente ao fato de que o Modernismo foi uma cultura nascida da experiência de temporalidades desiguais, em que o ritmo próprio da modernidade capitalista coexistia com formas de vida anteriores, o que gerava uma temporalidade diferencial e ao mesmo tempo simultânea. Quer dizer, trata-se de uma "cultura da modernização incompleta" (JAMESON, 20II, p. I9I). Como o argumento é retrospectivo, interessa a

17 Para uma documentação e um comentário excelentes do debate, ver o livro de Machado (2016). 

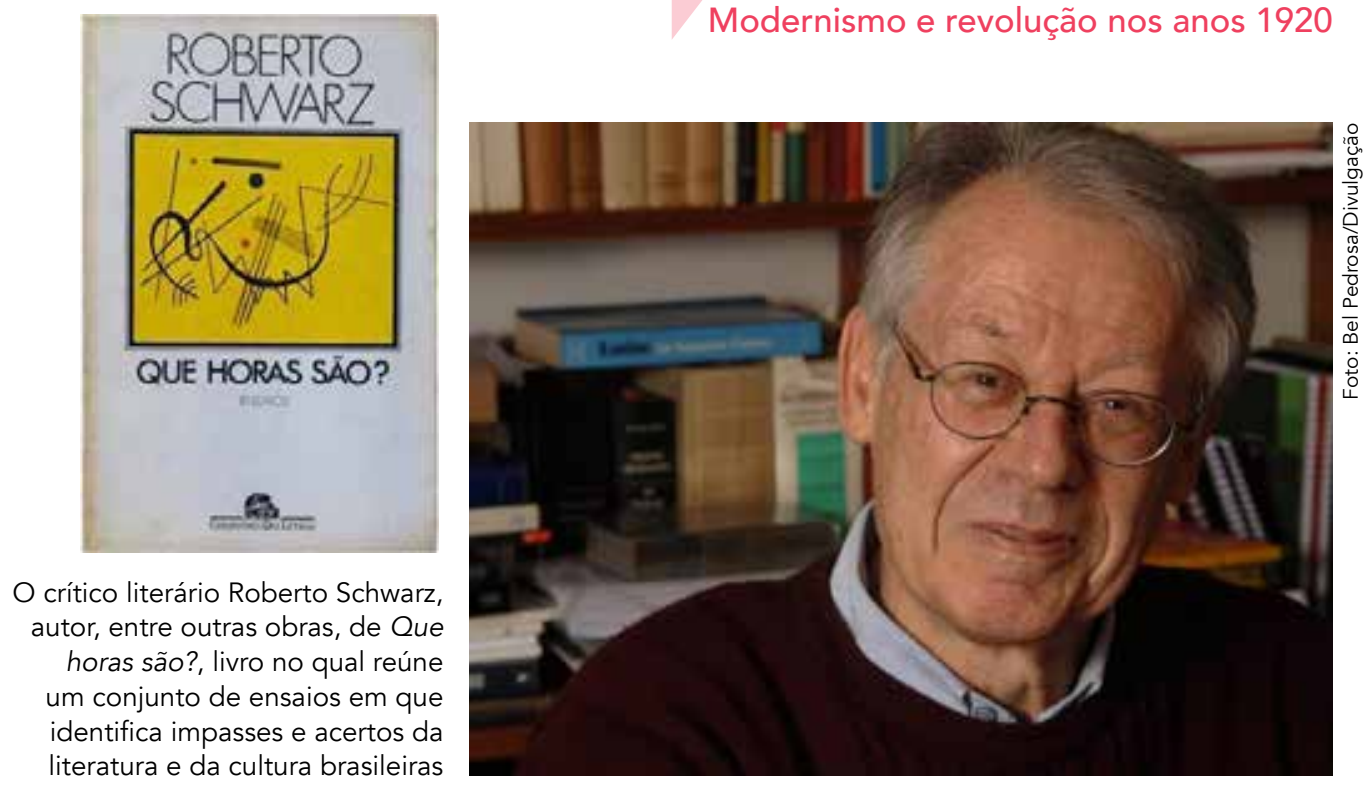

Jameson sobretudo sublinhar a situação contemporânea, em que o capitalismo do fim do século XX eliminou os lugares dessa experiência e criou um clima geral de simultaneidade espaçotemporal, na qual a antiga consciência modernista das coisas perde totalmente seu referente. Observe-se que, nos anos 1950, Adorno formulava exatamente o mesmo argumento a seu modo, dizendo que na relação entre cultura e sociedade há uma "dialética do não contemporâneo":

Somente onde o desenvolvimento em direção ao mundo administrado, à modernidade social, ainda não se impôs totalmente, como na França ou na Áustria, é que floresce a modernidade estética, as vanguardas. Onde, no entanto, a realidade se encontra totalmente no padrão contemporâneo, a consciência é tendencialmente nivelada. Quanto mais ela se adapta à realidade integral sem atritos, mais é desencorajada a ir além do que existe (ADORNO, 20I6, p. 136, tradução nossa).

O esquema histórico de explicação foi também secundado por Perry Anderson. Este recorre a uma tese de Arno Mayer, cujo livro A força da tradição (MAYER, 1987) chegou a ser traduzido no Brasil, mas creio que restem poucos de seus leitores. $\mathrm{O}$ argumento contraintuitivo de Mayer é que, ao contrário do que diz nosso senso comum histórico, somente poucos lugares podiam ser ditos plenamente modernos no início do século XX, pois na maior parte da Europa a modernização consistia apenas em ilhas cercadas por águas de persistência do Antigo Regime por todos os lados. O quadro sofrerá mudanças, mas sem ser eliminado, depois da Primeira Guerra Mundial, desaparecendo depois da Segunda Guerra. Em síntese: presença da contemporaneidade dos não contemporâneos em boa parte da Europa até a Segunda Guerra Mundial. No argumento de Perry Anderson, as consequências no plano da imaginação desse quadro foram notáveis, sendo essenciais para o modernismo estético. Este, em vez de ser expressão artística dos países plenamente contemporâneos do nível alcançado de modernidade, era produzido na verdade nos países onde a modernidade corria perante um grande pano de fundo ainda agrário, aristocrático, quando não feudal. Isso beneficiava, em vez de reprimir, o ímpeto modernista, graças a um condicionamento 
triangular composto por: a) uma tradição de arte acadêmica, contra a qual se tratava de romper, mas que também fornecia códigos e recursos estéticos a serem aproveitados criticamente; b) a experimentação com novidades tecnológicas de uma perspectiva mais ingênua, em que as relações de produção às quais elas devem sua existência ainda não apareciam em países mais atrasados, o que permitia alimentar um entusiasmo incendiário com as novas técnicas, cujo futuro ainda era impreciso; c) o baixo desenvolvimento capitalista, uma burguesia fraca e um proletariado ainda não integrado davam mais folga à esperança revolucionária de que esse sistema não precisaria predominar, o que punha a esperança de sua supressão na ordem do dia. Daí o resumo tripartite de Anderson (1986, p. 9): “O Modernismo europeu nos primeiros anos deste século [XX] floresceu assim no espaço situado entre um passado clássico ainda utilizável, um presente técnico ainda indeterminado e um futuro político ainda imprevisível."

Note-se um ar de família muito comum nas diferentes argumentações que estamos acompanhando até aqui: ao falar do Modernismo, Anderson e Jameson insistem em falar em temporalidades diferenciais, como Bloch defendia uma concepção multilinear de capitalismo; comentando os textos de Marx sobre o caso russo, Löwy também fala em concepção multilinear da história e Shanin se interessou sobretudo pela abertura do Marx tardio aos desenvolvimentos heterogêneos na periferia do capitalismo. Em todo caso, trata-se de criticar uma concepção evolutiva, etapista e unilinear da história, mostrando como a resistência e os modernismos estéticos dependiam de formas de modernização incompletas, que deixavam o espaço necessário para respirar o desejo subversivo por uma ordem diferente.

E quanto a Oswald? Em "Discutindo com Alfredo Bosi”, Roberto Schwarz retoma aquela descrição da utopia oswaldiana de que partimos:

Observem-se os manifestos de Oswald, que meio na piada jogam com a visão de um caminho de progresso sui generis, onde os lados simpáticos de nossa informalidade pré-burguesa - devidos à herança colonial — se combinariam sem sacrifício à experimentação técnica e libertária da arte de vanguarda, criando um exemplo revolucionário para o mundo, uma sociedade ao mesmo tempo espontânea e avançada, isenta dos males da civilização do presente (SCHWARZ, I999, p. 82).

Um caso exemplar de contemporaneidade dos não contemporâneos, como se vê: não é que a informalidade herdada dos tempos de colônia fosse aproveitável por si só, mas é sobretudo sua contemporaneidade com elementos da civilização adiantada que tornava possível uma combinação única e eufórica:

Naqueles anos, marcados pela crise da ordem liberal e capitalista, pelo fascismo e pela Revolução Soviética, os traços não burgueses decorrentes de séculos de segregação apareciam à imaginação sob prismas inesperados. Além de obstáculos ao progresso, figuravam também como inspiração e base presente para um futuro melhor, despido das alienações contemporâneas. Nesse sentido, note-se a promessa de naturalidade e graça que a sujeição apenas parcial do povo ao dinheiro, à gramática normativa, a modalidades modernas do trabalho, ao Estado, à Igreja oficial etc. parecia encerrar para os modernistas (SCHWARZ, 1999, p. 83). 
A modernização incompleta, justaposta a elementos populares legados pelo passado, permitia não apenas resistir aos efeitos negativos e indesejáveis do progresso, que é encarado em chave crítica, mas aproveitar como que ludicamente seus elementos mais interessantes. Da mesma forma, a tradição não é encarada abstratamente, sendo evidente que não é seu aspecto tradicionalista que interessa incorporar, mas o ângulo popular, informal e folclórico. Em todo caso, o que se entende por modernização, atraso, progresso etc., fica sempre retirado dos lugares comuns.

Retomando essa utopia oswaldiana à luz do estudo comparativo com teóricos críticos do centro do capitalismo (e vice-versa), o que sobressai é que a relação distanciada e livre com a modernidade, beneficiada por seu desenvolvimento desigual, e que a elaboração alegórica do Brasil feudal-burguês como via própria e não burguesa para uma sociedade superior original, aparecem não apenas como peculiaridades do Modernismo brasileiro, mas o Modernismo enquanto tal dependia dessa mesma combinação de temporalidades diferenciais, que aqui estariam reunidas de maneira exemplar. Como já citamos, Oswald gostava de brincar dizendo que já tínhamos o comunismo e o surrealismo e que, portanto, bastava ver as coisas com olhos livres para colher a poesia pronta nos fatos. As vanguardas aqui se realizavam sem esforço. Na mesma linha, o programa primitivo das vanguardas, conquistado a duras penas na Europa, aqui jorrava da vida cotidiana. Nesse espírito, Schwarz destacou como fazia parte do programa oferecer o Brasil como exemplo ao mundo. Essa era a via própria, bastante bem-humorada, pela qual Oswald contemporizava nossa não contemporaneidade, o que valeria então para o Modernismo internacional como um todo. Digamos que é que como se fosse mais fácil ser modernista no Brasil do que na Europa, já que a dialética da não contemporaneidade de que o movimento depende era aqui um fato ainda mais saliente.

Quando passamos a Marx e notamos a extrema proximidade entre essas reflexões e as intervenções do crítico materialista na questão russa entre I875 e I88I, então vemos como nossos modernistas - pois muito do que dissemos aqui encontraria paralelo em Mário de Andrade também - elaboravam esquemas que coincidiam com ideias que Marx estava desenvolvendo no último período de sua vida a respeito das chances históricas únicas que a dialética da não contemporaneidade gerada pelo desenvolvimento desigual do capitalismo pulverizava na periferia do sistema. A esperança de queimar a fase burguesa de desenvolvimento, aproveitando estruturas supostamente arcaicas e os ganhos mais avançados da civilização capitalista, parecia então estar entrando na cena da história contemporânea com bastante força, movimento ao qual nossos modernistas estavam somando esforços de maneira espontânea, sem conhecimento dessas relações.

O estudo comparado dessas propostas indica, abstraindo as diferenças, que existe um fundo comum apontando alternativas globais que buscavam dar relevância para o atraso relativo na história contemporânea como um todo. Em todos esses casos, tratava-se de: a) questionar a concepção evolutiva e unilinear do progresso do capitalismo, tanto como fato quanto como norma a ser seguida; b) revisar a natureza própria do capitalismo, agora entendido como desenvolvimento desigual e combi- 
nado capaz de criar situações heterogêneas, não obedecendo a um mesmo esquema sempre; c) reconhecer que, para se beneficiar dos ganhos civilizatórios, não é preciso repetir endogenamente as etapas das quais eles resultam; d) ganhar para o futuro pós-burguês as virtudes do passado pré-burguês, que ofereciam resistência às regressões geradas pela racionalização capitalista.

Em todos esses pontos, o saldo principal é sempre fugir a uma concepção tecnicista e progressista, no mau sentido, da modernização capitalista, que levou parcela da esquerda, no mundo inteiro, a desenvolver uma afinidade prática bastante prejudicial com o curso do mundo contemporâneo. No caso do Brasil, país endemicamente marcado pelo descompasso entre sua realidade e a norma civilizada, que exigiria saltos de desenvolvimento para acertar o passo com o centro, essa concepção oferecia um elemento crítico interessante, mas muito ignorado pelo progressismo que vigorou e ainda vigora muito por aqui - o "solzinho progressista", na fórmula lapidar de nosso autor (ANDRADE, I972b, p. I48).

* Graduado em Filosofia e em Ciências e Humanidades pela Universidade Federal do $A B C$ (UFABC), onde realizou pesquisa sobre Crítica e crise, de Reinhardt Koselleck. Mestre em Filosofia pela mesma instituição, mediante pesquisa sobre o debate entre Jürgen Habermas e Hans-Georg Gadamer. Doutorando em Filosofia na Universidade de São Paulo (USP), desenvolvendo pesquisa sobre a relação entre história e interpretação em Theodor W. Adorno. E-mail: feliperibeiro1848@gmail.com

Texto recebido em 9 de setembro de 2021; aprovado em 11 de Janeiro de 2022. 
ADORNO, Theodor W. Kultur und Verwaltung. In: Gesammelte Schriften 8: Soziologische

Schriften I. Frankfurt am Main: Suhrkamp, 2016.

ANDERS, Günther. Le temps de la fin. Paris: L'Herne, 2007.

ANDERSON, Perry. Modernidade e revolução. Novos Estudos Cebrap, São Paulo, n. 14, p. 2-15, 1986.

ANDRADE, Oswald de. A marcha das utopias. In: Obras completas 9: do pau-brasil à antropofagia e às utopias. Rio de Janeiro: Civilização Brasileira, 1978a.

Manifesto antropofágico: In: Obras completas 9: do pau-brasil à antropofagia e às utopias. Rio de Janeiro: Civilização Brasileira, 1978b.

Manifesto da poesia pau-brasil. In: Obras completas 9: do pau-brasil à antropofagia e às utopias. Rio de Janeiro: Civilização Brasileira, 1978c.

Obras completas 5: Ponta de lança. Rio de Janeiro: Civilização Brasileira, 1972a.

Obras completas 7: poesias reunidas. Rio de Janeiro: Civilização Brasileira, 1972b.

Obras completas 10: Telefonema. Rio de Janeiro: Civilização Brasileira, 1976.

. Um aspecto antropofágico da cultura brasileira: o homem cordial. In: Obras completas 9: do pau-brasil à antropofagia e às utopias. Rio de Janeiro: Civilização Brasileira, 1978d.

ARANTES, Paulo. 0 novo tempo do mundo e outros estudos sobre a era de emergências. São Paulo: Boitempo, 2014.

Sentimento da dialética: dialética e dualidade segundo Antonio Candido e Roberto Schwarz. São Paulo: [s.n.], 2021.

BENJAMIN, Walter. A obra de arte na época de suas técnicas de reprodução. In: BENJAMIN, Walter et al. Textos escolhidos. São Paulo: Abril Cultural, 1983. (Coleção Os Pensadores.)

BLOCH, Ernst. Heritage of our times. Oxford: Polity Press, 1991.

CAMPOS, Haroldo de. Uma poética da radicalidade. In: ANDRADE, Oswald de. Obras completas 7: poesias reunidas. Rio de Janeiro: Civilização Brasileira, 1972.

CANDIDO, Antonio. Dialética da malandragem. In:

O discurso e a cidade. 5. ed. Rio de Janeiro: Ouro sobre Azul, 2015.

Digressão sentimental sobre Oswald de Andrade. In: CANDIDO, Antonio. Vários escritos. São Paulo: Duas Cidades, 1970.

Literatura e cultura de 1900 a 1945. In:

Literatura e sociedade: estudos de teoria e

história literária. São Paulo: Companhia Editora Nacional, 1973.

DANTAS, Vinícius. O capital e o canibal: a arte do Telefonema de Oswald de Andrade. In: Terceira Margem, Rio de Janeiro, n. 12, p. 210-227, 2015.

DÓRIA, Carlos A. O dual, o feudal e o etapismo na teoria da revolução brasileira. In: MORAES, João Quartim de (Org.). História do marxismo no Brasil. Campinas: Editora Unicamp, 1998. v. 3.

ENGELS, Friedrich. Literatura de refugiados. In: MARX, Karl; ENGELS, Friedrich. Luta de classes na Rússia. São Paulo: Boitempo, 2013a.

ENGELS, Friedrich. Posfácio [a Questões sociais da Rússia], 1894. In: MARX, Karl; ENGELS, Friedrich. Luta de classes na Rússia. São Paulo: Boitempo, 2013b.

FROMM, Erich. Die sozialpsychologische Bedeutung der Mutterrechtstheorie. Zeitschrift für Sozialforschung, Paris, n. 3, v. 2, p. 196-227, 1934.

JAMESON, Fredric. O fim da temporalidade. In: ArtCultura, Uberlândia, v. 13, n. 22, p. 187-206, 2011.

Postmodernism: or, the cultural logic of late capitalism. Durham: Duke University Press, 1991. 
LÖWY, Michael. Introdução: dialética revolucionária contra a ideologia burguesa do progresso. In: MARX, Karl; ENGELS, Friedrich. Luta de classes na Rússia. São Paulo: Boitempo, 2013.

LÖWY, Michael; SAYRE, Robert. Revolta e melancolia: o romantismo na contracorrente da modernidade. São Paulo: Boitempo, 2015.

LUKÁCS, György. Die Gegenwartsbedeutung des kritischen Realismus (1957). In: Werke IV: Probleme des Realismus I. Berlim: Luchterhand, 1971a.

Zur Frage der Satire (1932). In: Werke IV: Probleme des Realismus I. Berlim: Luchterhand, $1971 \mathrm{~b}$.

MACHADO, Carlos E. J. Um capítulo da história da modernidade estética: debate sobre o expressionismo. São Paulo: Editora Unesp, 2016.

MAMMì, Lorenzo. A fugitiva: ensaios sobre música. São Paulo: Cia das Letras, 2017.

MARX, Karl. Carta à redação da Otechestvenye Zapiski, 1877. In: MARX, Karl; ENGELS, Friedrich. Luta de classes na Rússia. São Paulo: Boitempo, 2013a.

Primeiro ao quarto esboços e carta a Vera Ivanovna Zasulitch. In: MARX, Karl; ENGELS, Friedrich. Luta de classes na Rússia. São Paulo: Boitempo, $2013 \mathrm{~b}$.

MARX, Karl; ENGELS, Friedrich. Prefácio à edição russa do Manifesto comunista, 1882. In: Luta de classes na Rússia. São Paulo: Boitempo, 2013.

MAYER, Arno J. A força da tradição: a persistência do Antigo Regime (1848-1914). São Paulo: Companhia das Letras, 1987.

ROSENFELD, Anatol. O processo histórico e a energia atômica. In: Texto/contexto II. São Paulo: Perspectiva, 1993.

SCHWARZ, Roberto. As ideias fora do lugar. In: Ao vencedor as batatas. 6. ed. São Paulo: Companhia das Letras, 2012.

Complexo, moderno, nacional e negativo. In: . Que horas são?. São Paulo: Companhia das Letras, 1987a.

Discutindo com Alfredo Bosi. In: Sequências brasileiras. São Paulo: Companhia das Letras, 1999.

Nacional por subtração: In: Que horas são?. São Paulo: Companhia das Letras, 1987b. O bonde, a carroça e o modernista. In: Que horas são?. São Paulo: Companhia das Letras, 1987c.

Pressupostos, salvo engano, de. Dialética da malandragem. In: Que horas são?. São Paulo: Cia das Letras, 1987d.

SHANIN, Teodor. Late Marx: gods and craftsmen. In: (Ed.). Late Marx and the Russian road: Marx and "the peripheries of capitalism". New York: Monthly Review Press, 1983.

WADA, Haruki. Marx and the revolutionnary Russia. In: SHANIN, Teodor (Ed.). Late Marx and the Russian road: Marx and "the peripheries of capitalism". New York: Monthly Review Press, 1983.

ZASULITCH, Vera I. Carta a Karl Marx, 16 fev. 1881. In: MARX, Karl; ENGELS, Friedrich. Luta de classes na Rússia. São Paulo: Boitempo, 2013. 